\title{
El Edificio de los Frisos de Ánimas Altas. Ser paraCas EN El VAlle bajo de ICA
}

\author{
Aïcha Bachir Bacha ${ }^{a}$
}

\begin{abstract}
Resumen
En este articulo, se presentan y se discuten los resultados de las recientes investigaciones llevadas a cabo en el marco del Programa Arqueológico Ánimas Altas, Ica, Perú. Se enfatizan las excavaciones realizadas en un edificio decorado con frisos. El análisis de la cultura material de este edificio —en particular, de los iconos plasmados en los frisos-ofrece algunas interpretaciones no solamente respecto a la simbologia y cosmovisión paracas; también, arroja luces sobre aspectos relacionados con dinámicas identitarias y territoriales de las formaciones sociales paracas en el valle bajo de Ica. Los iconos plasmados en los frisos apoyan la idea según la cual las interacciones de los paracas no se limitaron a la sierra adyacente. Más aún, existen nexos con la costa norte y central desde épocas remotas que quedan por investigar. Las variaciones estilisticas y tecnológicas observadas en el Edificio de los Frisos - que no se manifiestan en diacronia-pueden revelar varios fenómenos, entre ellos, la ocupación del territorio por varios grupos que formaron entidades sociopoliticas en la época Paracas Tardio. Las comparaciones entre los datos proporcionados por las excavaciones del Edificio de los Frisos con los de otros sitios permitirán formular interpretaciones e hipótesis sobre el espacio politico y cultural de los paracas.
\end{abstract}

Palabras clave: Paracas, territorio, arquitectura, iconografia, formaciones sociales, interacciones

Abstract

ANIMAS ALTAS” “FRIEZES BUILDING”. BEING PARACAS AT THE LOWER ICA VALLEY

This paper presents and discusses the results of recent investigations carried out by the Animas Altas Archaeological Program, in the Ica department, southern Peru. A particular emphasis is put on the excavations conducted at a frieze-decorated building. The analysis of the material culture registered in this building, particularly of the icons depicted on the friezes, not only offers some interpretations regarding Paracas symbology and cosmovision but also sheds lights on critical aspects related to identity as well as the territorial dynamics of the Paracas social formations from the lower section of the Ica valley. Furthermore, imagery depicted on friezes support the idea that social interactions promoted by the Paracas were not limited to the adjacent highland. Even more, potential links with the north and central coast from remote times need to be further investigated. The stylistic and technological variations registered at the "Building of Friezes" - which are not diachronically manifested, can reveal diverse phenomena such as the occupation of the territory by several groups that gave shape to socio-political identities in Late Paracas times. The comparison between the data obtained from the excavation at the "Building of Frizes" and other Paracas sites 'will allow Paracas scholars to formulate interpretations and hypotheses about both the political and cultural spaces of the ancient Paracas.

Keywords: Paracas, territory, architecture, iconography, social formations, interactions

a Ecole des Hautes Etudes en Sciences Sociales, Paris Correo electrónico: bacha@ehess.fr 


\section{Introducción}

A menudo difíciles de entender al ser concebidas a través del filtro del pensamiento occidental y catalogadas como sociedades sin «escritura», sin «Estado», y a veces sin «urbanismo», las poblaciones andinas — incluidas las prehuari y las preinca — generaron en realidad sus propias representaciones del mundo material e idéel. No obstante, el área andina, al igual que otras regiones del mundo, posee su propio proceso histórico, tal como lo atestiguan una abundante documentación arqueológica y sistemas iconográficos formalizados. Por consiguiente, el área andina no debe estar confinada a una prehistoria que supuestamente terminaría con la conquista española. Es bajo esta óptica y a la luz de los recientes descubrimientos arqueológicos que, en el marco del Programa Ánimas Altas, nos acercaremos a la cultura Paracas, la cual no se limita a un solo estilo cerámico o textil.

Esta investigación es la continuación lógica de una reflexión articulada en torno a la naturaleza y la configuración de los grandes establecimientos paracas, y a las identidades de los grupos que ocuparon e interactuaron en sus territorios. Se trata de caracterizar procesos y desarrollos culturales propios de las sociedades prehispánicas de la costa sur del Perú y de la búsqueda de entender su complejidad desde una perspectiva andina (Bachir Bacha 2007, 2013; Bachir Bacha y Llanos 2013). Para ello, examinamos constantemente los contextos arqueológicos in situ y la cultura material en su conjunto. Estos datos empíricos primarios constituyen el fundamento de la interpretación y la teorización.

Por otro lado, enfatizar en el análisis de la arquitectura —un tema muy poco documentado en la literatura especializada - adquiere pleno sentido en la medida que la arquitectura constituye probablemente un marcador cultural y social más pertinente que objetos sujetos a circulación e intercambio, como es el caso de la cerámica y los textiles (Bachir Bacha 2016). De hecho, el objeto arquitectónico marca un territorio, y, en sus estructuras, se inscriben las técnicas y los saberes del grupo que ocupa el lugar. En general, los centros políticos-religiosos crecen y se remodelan con el paso del tiempo, y los nuevos edificios se construyen encima de los antiguos. Por lo tanto, los monumentos conservan la historia y la memoria del lugar. De ser así, la complejidad de un establecimiento no se encuentra necesariamente en las imponentes dimensiones de sus edificios, sino en la sedimentación histórica de estos.

Asimismo, el enfoque en otros materiales va más allá del análisis tipológico. La heterogeneidad estilística (fases o subestilos de cerámica y textiles) que no se manifiesta siempre en diacronía es considerada como otro indicador de complejidad social. Explorar esta variedad desde una perspectiva de dinámicas sociales y territoriales permite proponer otros modelos de interpretaciones $\mathrm{y}$, a la vez, salir del discurso tipológico que nos aleja de la dimensión humana del objeto arqueológico.

Siguiendo estas líneas de investigación y a partir de una perspectiva comparativa, en este artículo, se presentan y se discuten los resultados de las excavaciones realizadas en el Edificio de los Frisos, uno de los monumentos principales del Complejo Arqueológico Ánimas Altas/Ánimas Bajas durante las temporadas 2014 a 2016. Se trata de un estudio que aspira a ir más allá de la restitución de la secuencia ocupacional, del diseño y de las técnicas constructivas de este monumento. Esta investigación explora la naturaleza de las actividades realizadas en el seno del Edificio de los Frisos, de la que se desprende el funcionamiento del sitio en la época Paracas Tardío (250 a.C. a 50 d.C.). Además, la singularidad de la cultura material del edificio en cuestión se presta a indagar aspectos relacionados con las formaciones sociopolíticas paracas en el valle bajo de Ica y a explorar sus dinámicas territoriales. En última instancia, contrastar los datos proporcionados por las excavaciones del Edificio de los Frisos con los de otros sitios permite formular interpretaciones e hipótesis sobre el espacio político y cultural de los paracas.

\section{Marco geográfico y cronológico}

El Complejo Arqueológico Ánimas Altas/Ánimas Bajas se encuentra ubicado en la cuenca de Callango, en el valle bajo de Ica, a 50 kilómetros al sur de la ciudad de Ica y a 30 kilómetros del 


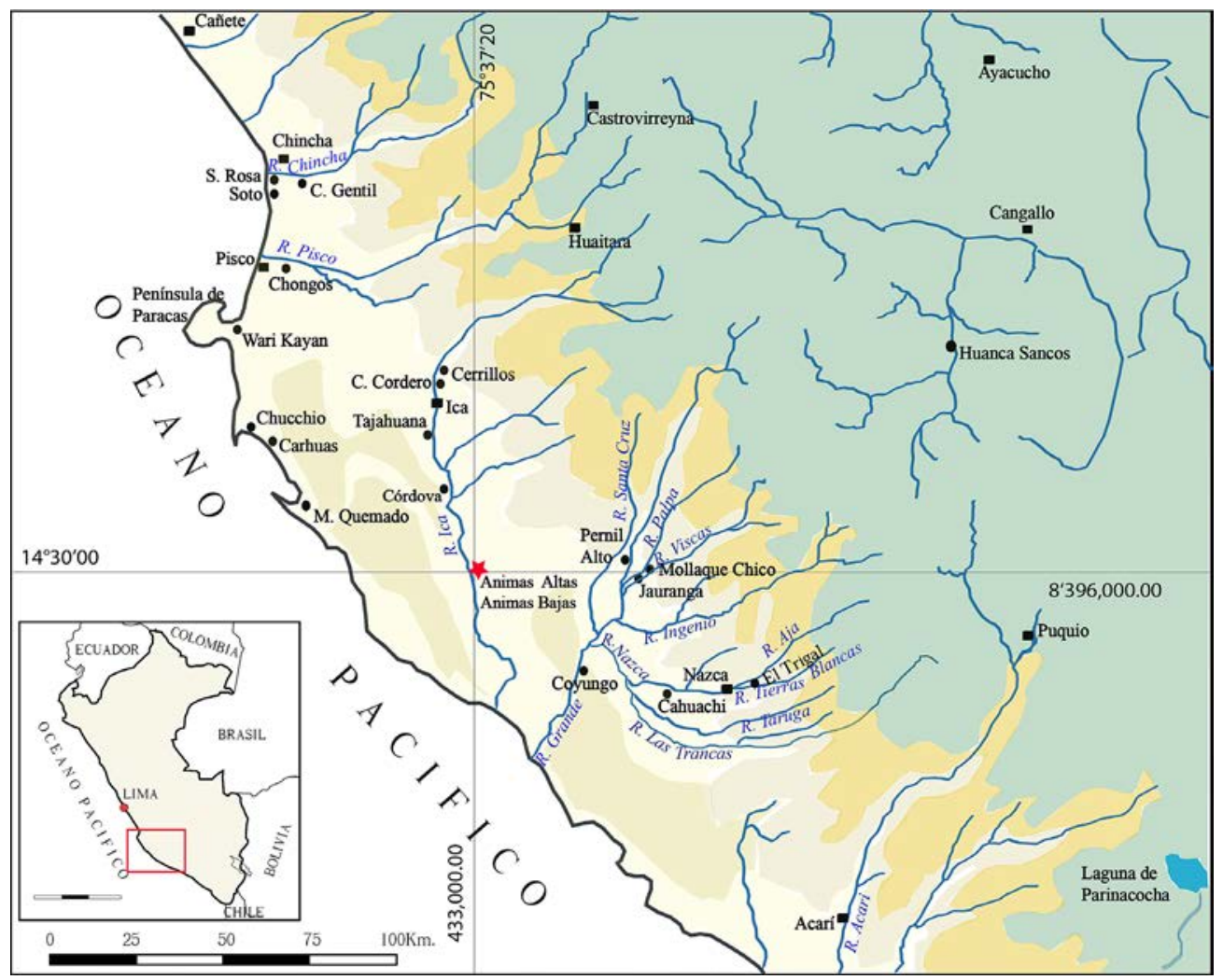

Figura 1. Ubicación del Complejo Arqueológico Ánimas Altas/Ánimas Bajas en la costa sur del Perú (elaboración del mapa: O. D. Llanos J. y A. Bachir Bacha).

océano Pacífico (Fig. 1). Localizado a 270 metros sobre el nivel del mar y a 1,50 kilómetros de la margen izquierda del río Ica, se extiende por más de dos kilómetros de norte al sur y alrededor de 800 metros del este a oeste en la Pampa del Cacique. El sitio forma parte de un territorio llano rodeado de cerros bajos, caracterizado por un clima árido y semicálido desértico, con precipitaciones muy escasas. A la altura de Callango, la actividad agrícola — aunque mucho menos intensiva de lo que se observa en el valle medio de Ica - invade desde la década de 1980 las franjas de las pampas aledańas al valle y destruye a su paso numerosos sitios arqueológicos.

El río Ica que abastece el agua necesaria para la agricultura y da origen al valle del mismo nombre tiene una configuración geomorfológica particular. Llegando a San Juan y enfrentándose con el tablazo de Ica cambia de dirección hacia el sur con un rumbo casi paralelo a la costa. A partir de la cuenca de Ocucaje hasta la boca del río, el cauce del río se vuelve angosto y seco, discurriendo a través de cuencas y cañones. Su encajonamiento está vinculado, por una parte, con la necesidad de atravesar los relieves costeros (más elevados, haciendo barrera) y, por otra, con que la región está sometida a un lento, pero regular, levantamiento. Ello explica la ausencia del cono de deyección en la porción baja del valle y la deposición de los sedimentos en su sección media (ONERN 1971).

El Complejo Arqueológico Ánimas Áltas/Ánimas Bajas forma parte de una red de antiguos establecimientos identificados a lo largo del valle bajo de Ica, asignables esencialmente al Horizonte Temprano (1000 a 200-100 a.C.) y el inicio del Intermedio Temprano (200-100 a.C. a 100 d.C.). En el marco de las investigaciones del Programa Arqueológico Ánimas Altas, las excavaciones de varios sectores pusieron a la luz las evidencias de una estratigrafía vertical y horizontal, que, cruzada con el análisis de la arquitectura y las asociaciones de cerámica y textiles, permiten esbozar una 
cronología relativa del sitio que corresponde a cuatro momentos constructivos. Si se toman en cuenta estos datos y los fechados obtenidos sobre materiales asociados a la cerámica ocucaje 8/9 procedente de Jauranga en el valle de Palpa (Unkel 2006: 71) y los fechados de un textil de Cerro Gentil en Chincha (Tantaleán et al. 2013: Tabla 1) asociado también a cerámica ocucaje 8/9, Ánimas Bajas/Ánimas Altas se ubicaría entre 400 a.C. a 50/100 d.C; y el Edificio de los Frisos, entre 250 a.C.a 50 d.C.

\section{Descripción del sitio}

Los edificios de Ánimas Altas/Ánimas Bajas se construyeron sobre una porción de pampa cubierta de capas de arcilla sedimentaria, de vetas de ocre y de pequeñas dunas. Estas fueron acondicionadas para emplazar las construcciones o incorporadas en la fundación de los edificios. El sitio abarca más de 90 hectáreas e incluye 100 montículos de planta ortogonal que albergan edificios, orientados de norte a sur, con una desviación de $30^{\circ}$ hacia el oeste. El más imponente de los montículos mide 190 metros de largo (de norte a sur), 80 metros de ancho (de este a oeste) y siete metros de altura (Fig. 2). Se observa un ordenamiento intencional en la articulación de los grupos de montículos; algunas estructuras conforman una unidad orgánica compuesta por una pirámide principal conectada a plataformas laterales; el ejemplo más representativo es el Edificio de los Frisos. Por lo general, el diseño arquitectónico de las estructuras es escalonado con plataformas cuya altura varía de 0,40 a dos metros. Los espacios abiertos ubicados entre los montículos constituyen a primera vista plazas y pasadizos. A pesar del avance agrícola y a la desaparición de varios montículos, esta configuración revela una arquitectura planificada, que integra edificios públicos, tumbas de dignatarios, áreas domésticas y de producción, así como cementerios (Bachir Bacha 2013).

Otra característica del sitio es la organización dual de su espacio. En Ánimas Altas, se pudo observar que los principales edificios públicos, las plazas, algunas plataformas bajas y dos cementerios se concentraban al norte de este sector, como testigos de las actividades esencialmente públicoceremoniales. Mientras, al sur de este núcleo, tres contextos situados en zonas llanas con vestigios de muros bajos, una concentración de batanes, restos de platos de alfarero y un basural, así como grandes áreas de quemas, son testimonio de actividades domésticas y/o de producción de artefactos. Más al sur, en Ánimas Bajas, pese al impacto de la expansión agrícola y de acciones intensas de huaquería, la organización dual se configura de este a oeste (Fig. 2). Un desnivel natural en el terreno divide el espacio en una parte alta del lado este, libre de inundaciones; y otra baja, del lado oeste, inundable por los desbordes cíclicos de río Ica. En ambas áreas, se documentaron edificios monumentales, espacios domésticos y de producción. Los cementerios se ubican en la parte alta (Bachir Bacha y Llanos 2013).

\section{Antecedentes}

Entre las décadas de 1940 y 1960, el sitio fue visitado sucesivamente por los arqueólogos Julio C. Tello, Lawrence Dawson y Dwight Wallace (Tello 1959; Menzel et al. 1964). En 1960, un sondeo fue realizado por Dawson en Ánimas Altas. Una década después, Carlos Williams y Miguel Pazos llevaron a cabo prospecciones en el valle de Ica, durante las cuales reconocieron dos importantes sitios: 14J01 y 14J03 (Williams y Pazos 1974), cuyas coordenadas geográficas corresponden a Ánimas Bajas/Ánimas Altas. Por su parte, Sarah Massey (1983) realizó una excavación en Ánimas Altas en 1982. Entre 1988 y 1990, Ánimas Altas/Ánimas Bajas fue nuevamente prospectado por Anita Cook (1994).

El hallazgo del primer friso paracas descubierto en la costa sur incumbe a Sarah Massey, quien excavó en un sector restringido de Ánimas Altas, ubicado en el flanco norte de lo que hemos designado Montículo 1 o «Edificio de los Frisos». Su excavación consistió en una trinchera de un metro de ancho dispuesta a lo largo de la fachada en «U» decorada con 11 figuras, según la autora 


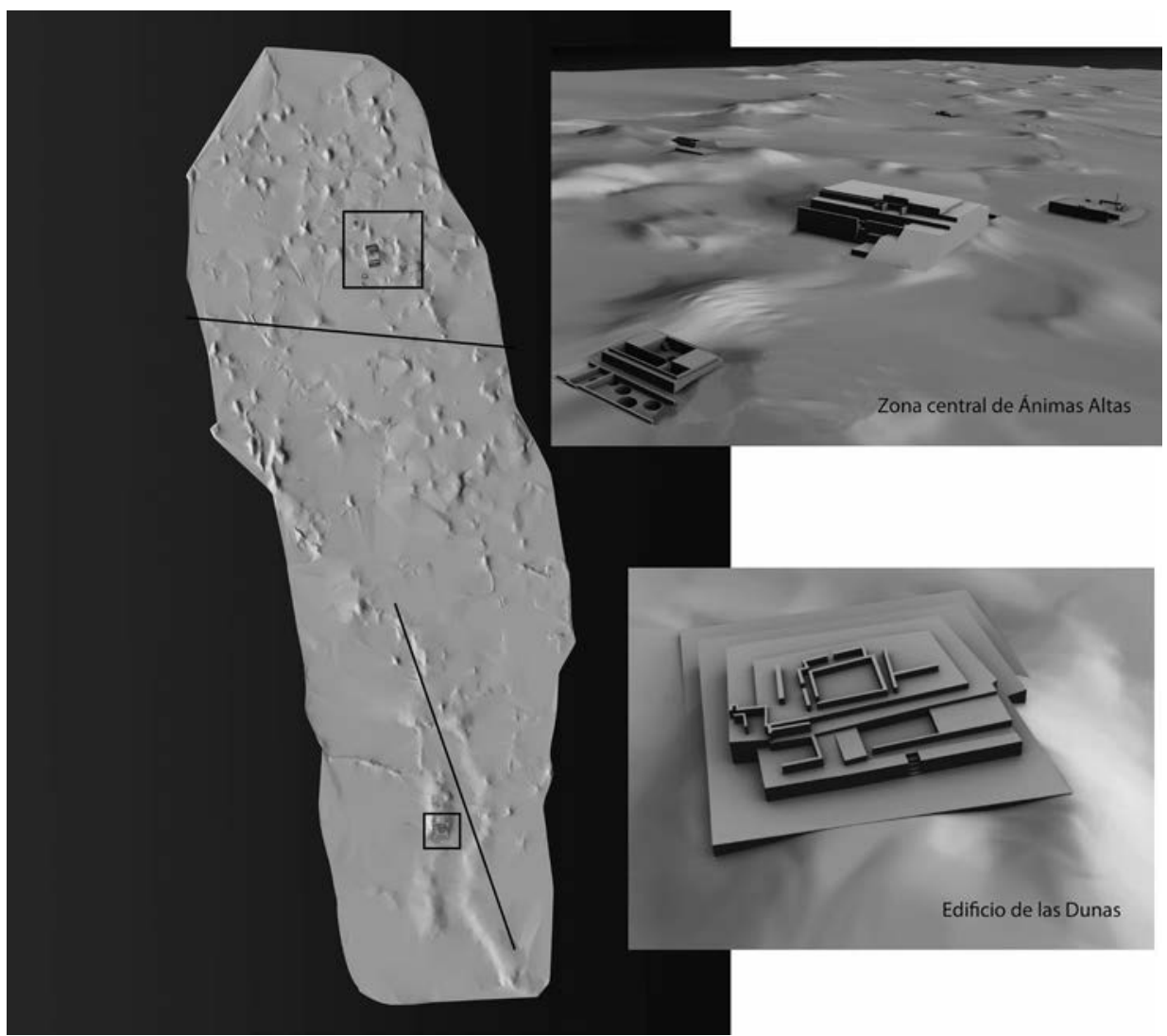

Figura 2. Reconstitución isométrica del Complejo Arqueológico Ánimas Altas/Ánimas Bajas (PAAA IP/VIZUA 2014)

(Massey 1983, 1990). Si bien la iconografía del friso fue analizada en una publicación, no se tienen referencias del resto del material asociado. Según Massey (1990: 148), esta iconografía representa principalmente al Ser Oculado, aunque varias figuras manifiestan afinidades con íconos cupisnique y chavín, o son designados como ocucaje 5, 6, 7 .

\section{Las investigaciones del Programa Arqueológico Ánimas Altas, Ica, Perú (PAAA, IP)}

Las investigaciones llevadas a cabo en el área de Callango en el marco del Programa Arqueológico Ánimas Altas ${ }^{1}$ se centran en la comprensión del funcionamiento y de la organización territorial de Ánimas Altas/Ánimas Bajas. La caracterización de la arquitectura paracas en el valle bajo de Ica es uno de los objetivos principales del programa.

Un logro importante del programa es haber excavado, entre los años 2009 a 2016, 10 sectores, con un total de 100 cuadrículas ( 2500 metros cuadrados) excavadas entre uno a 5 metros de profundidad, según las características de los contextos. Cada área excavada fue dividida en unidades de cinco por cinco metros para que, luego, sean reemplazadas por los espacios arquitectónicos (recinto, corredor, plaza, depósitos, etc.) revelados por la excavación. Para el registro estratigráfico, se empleó el método de Harris (unidades estratigráficas). Debido a su grosor, que podía llegar hasta cuatro metros, la excavación de los rellenos siguió niveles arbitrarios definidos en función de la naturaleza de los rellenos y los materiales descubiertos.

Las excavaciones permitieron sacar a la luz contextos arqueológicos caracterizados por una rica y variada cultura material. Luego de retirar la capa superficial y limpiar los escombres dejados 
por los huaqueros, las secuencias estratigráficas documentadas en los montículos y otros sectores incluyen diferentes niveles arquitectónicos (capa de sello en arcilla compacta, rellenos constructivos, muros de recintos y corredores, depósitos, corrales, muros de contención, apisonados, pisos, sustrato natural nivelado). Gran parte del material arqueológico proviene de rellenos. Asimismo, desde 2009, nuestro programa ha descubierto cuatro frisos.

Sobre la base de estos primeros resultados de los trabajos de campo y de los análisis de contextos arqueológicos debidamente documentados, Ánimas ha sido caracterizado como un centro políticoreligioso residencial, cuya cultura material testimonia la existencia de «urbanismo» en la costa sur del Perú (Bachir Bacha 2013; Bachir Bacha y Llanos 2013). El territorio de Ánimas no se limita a su zona monumental: integra sitios satélites; espacios explotados, transitados; $\mathrm{y}$-principalmentelugares sagrados socializados, cargados de sentido para los paracas. Estos «segmentos» de territorio dependían simbólica, política y económicamente de Ánimas (Bachir Bacha e.p.).

\section{Las excavaciones en el Edificio de los Frisos}

\subsection{Secuencia constructiva, diseño arquitectónico y materiales asociados}

El Montículo 1, bautizado como Edificio de los Frisos, ubicado al extremo norte del sitio, es una pirámide de 35 metros (E-O) por 60 metros (NS) y cinco metros de altura. Dando hacia plazas, está flanqueado por el norte y el sur por dunas que superan seis metros de alto (Fig. 3b); asimismo, de este edificio, dependen plataformas bajas. En la fotografía aérea, se perfila una estructura de planta en "U» sobre una pendiente moderada abierta hacia el norte, mientras que los flancos sur, este y oeste del montículo tienen pendientes más empinadas (Fig. 3a).

Los resultados de las excavaciones en área (2014-2016) permitieron distinguir un primer nivel de uso y cuatro etapas constructivas (Fig. 4). Además de los frisos descubiertos en 1982 (Massey 1983) y conservados, documentados y analizados en el marco del PAAA, IP entre 2012 y 2014 (Bachir Bacha y Llanos 2013), en la últimas temporadas (2015-2016), se descubrieron otros: un friso grabado en el muro de un altar hallado en la sección sur del montículo y otro modelado en el muro de un recinto ubicado en la cima del montículo. Además de los materiales dispersos en los rellenos, también se identificaron restos de actividades, como quemas, áreas de concentración de materiales y depósitos de ofrendas, todos ellos evidencias de eventos relacionados con la construcción de los edificios, sus remodelaciones y su enterramiento. En este contexto, se debe destacar la presencia de numerosas ofrendas (malacológico, vegetal, mineral, lítico, textil, cerámica, óseo humano y animal, carbón, orgánico) halladas sobre los pisos, en hoyos y en los rellenos (Fig. 5).

6.1.1. El primer nivel de uso. Identificado en el lado norte del montículo, este nivel constituye el sustrato natural acondicionado aplanando sus sinuosidades y llenando sus depresiones con un relleno de tierra, protegido por una capa de arcilla fina (Fig. 6). Varios hoyos poco profundos, con un diámetro (entre 13 y 28 centímetros) y profundidad variables (entre 11 y 14 centímetros), más o menos alineados y con orientación este-oeste, intruyen este piso. Se trata probablemente de hoyos de postes que soportaban estructuras ligeras o fueron cavados para depositar ofrendas antes del enterramiento del primer edificio. De hecho, en algunos de ellos, se halló una mota de algodón de color marrón asociada a un fragmento de textil llano bordado con hilos rojo y verde, así como restos de coprolitos humanos. Por otro lado, la excavación del flanco oeste del montículo también reveló un primer piso acondicionado en el sustrato natural, ubicado a 1,70 metros del nivel de las primeras plataformas.

En el estado actual de las investigaciones, es difícil entender cuáles son las estructuras con las que se vinculaban estos pisos sin retirar los rellenos de las construcciones posteriores. Sin embargo, podemos suponer que estos primeros vestigios formaban parte de las construcciones que proliferan en Ánimas Altas asignados a la segunda fase de la secuencia del sitio o son el resultado de la nivelación del sustrato natural para asentar las nuevas plataformas. 


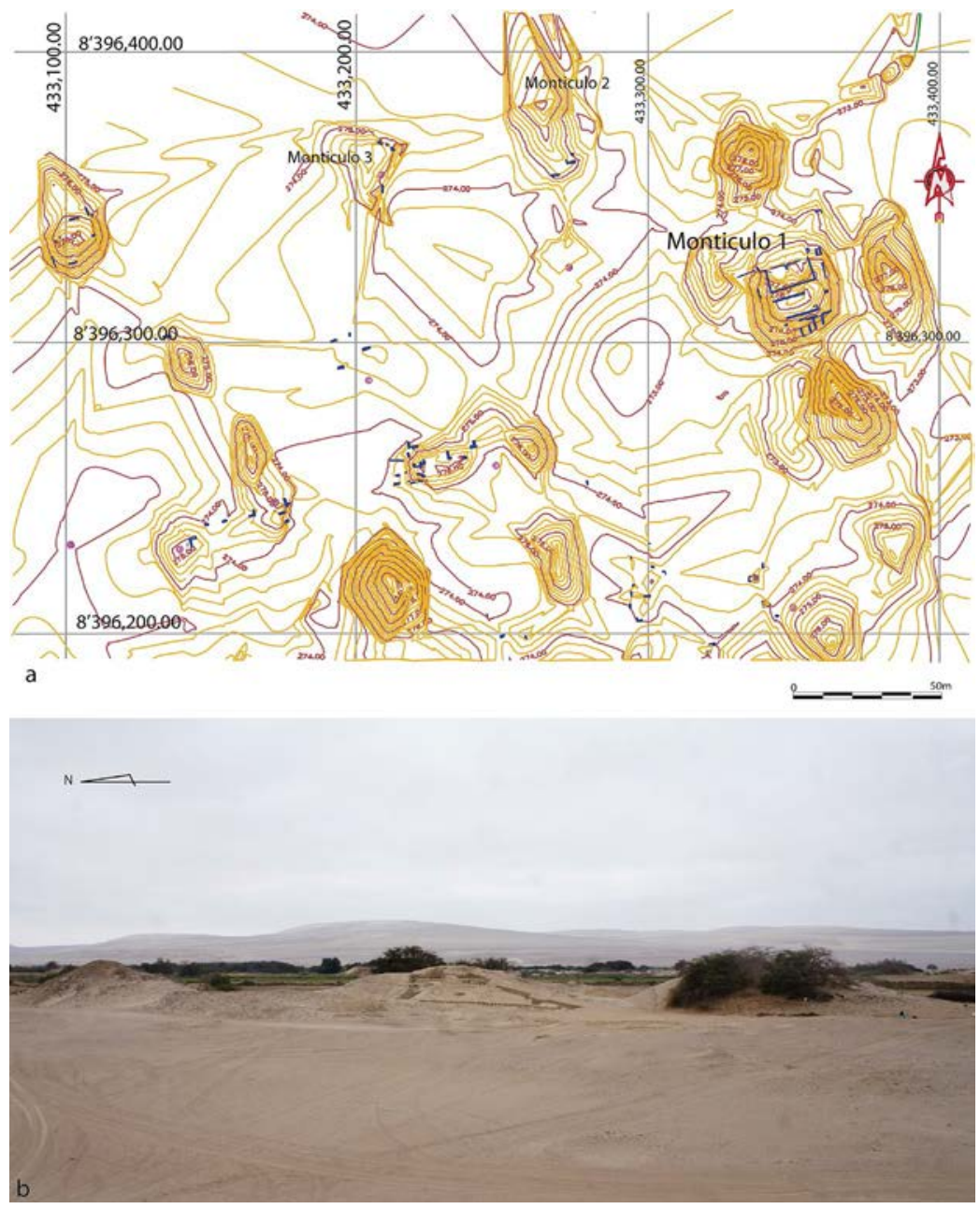

Figura 3. a. Plano topográfico de la sección norte de Ánimas Altas; b. vista desde el oeste del Montículo 1 (elaboración del plano: R. Rojas, O. D. Llanos J. y A. Bachir Bacha; foto: A. Bachir Bacha).

6.1.2. Edificio 1. Los rellenos que cubren los primeros vestigios sirven de base y definen los volúmenes del primer edificio. Se trata de una estructura de planta rectangular compuesta por dos plataformas (1,70 metros de altura) y una serie de recintos orientados hacia espacios abiertos (Fig. 7A). En la sección norte del montículo, el relleno compuesto de terrones, capas de vegetal (chala de maíz) y tierra (1,50 metros de grosor) cubre el primer nivel de uso (Fig. 6). Una capa de arcilla gruesa y compacta de aspecto irregular sella el relleno y cumple la función de piso de una gran rampa y de base para dos corrales laterales al oeste (Fig. 7a). Elevando el relleno, los constructores colocaron la tumba de un infante (lamentablemente, disturbada por la huaquería), cuyos restos yacían dentro una olla que contenía también un cuenco. En los rellenos que constituyen el cuerpo de la rampa, se halló también una acumulación de huesos humanos, material lítico pulido y tallado, pequeños bloques de arcilla, restos malacológicos (caracoles de lomas, conchas, almejas, choros), carbón y cerámica decorada mediante la técnica del negativo (Ocucaje 9-10).

La gran rampa da acceso a la primera plataforma o terraza (que mide más de 10 por 10 metros). En los rellenos que conforman el cuerpo de esta terraza, yacía un conjunto de restos de óseos (extremidades inferiores); pelo de camélido; restos botánicos, como ramas, pallar (Phaseolus lunatus) y maíz; restos malacológicos, como choros azules (Choromytilus chorus) y caracoles de lomas (Bostryx 


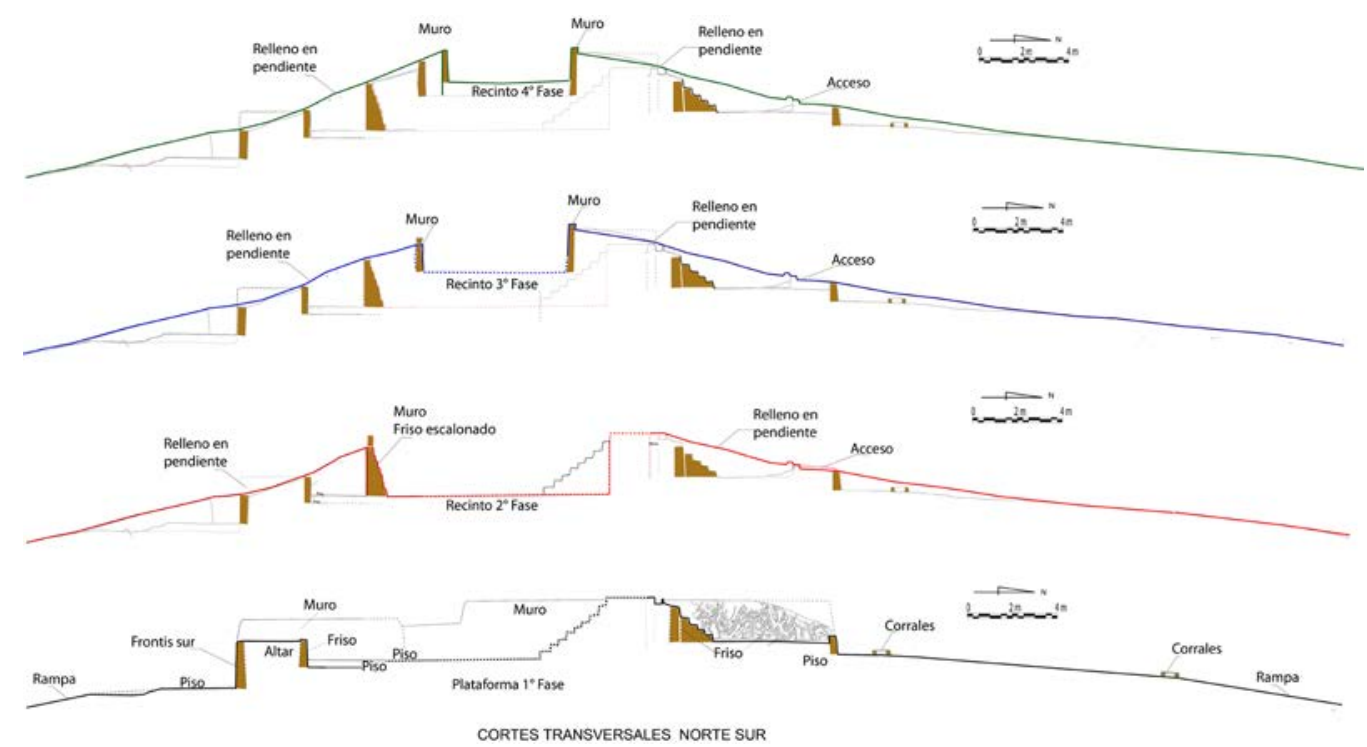

Figura 4. Cortes transversales norte-sur que ilustran las etapas constructivas y las remodelaciones del Edificio de los Frisos, PAAA IP temporadas 2015-2016 (elaboración del dibujo: O. D. Llanos).

scalariformis); y un fragmento de un textil llano. Sobre la terraza, se instalaron pequeños corrales (11 en el estado actual de la excavación) ortogonales alineados de este a oeste, probablemente usados como cuyeros (Figs. 6, 7a). De hecho, ofrendas de coprolitos de cuyes se hallaron en el relleno, mientras que otros se encontraron dentro de una olla.

La segunda plataforma de planta en «U» abriga un atrio cuyas paredes fueron grabadas con frisos (Figs. 6, 7a, 8). Porciones de muros visibles en la superficie del montículo sugieren la presencia de depósitos o quizás recintos laterales. La altura que separa la primera y la segunda plataforma, conectadas a través de un acceso, no excede los 40 centímetros.

Una escalera de cinco gradas adosada al frontis central del atrio, que lo divide en dos mitades más o menos iguales, conduce a la cima de la tercera plataforma. Esta escalera probablemente fue construida durante las remodelaciones del primer edificio, luego del sello de un acceso ubicado en el muro central del atrio. Este acceso conectaba posiblemente el atrio de los frisos con otros ambientes ubicados detrás, en la sección sur del edificio. Al oeste del acceso, adosada al muro central, se registró una tumba disturbada. Se trata de un pozo (80 centímetros de diámetro, 60 centímetros de profundidad) excavado en el piso del recinto y coronado con una estructura en bloques de arcilla sedimentaria cubierta por troncos de huarango. La limpieza del pozo permitió registrar la impronta de un gran recipiente (Figs. 6, 8).

En la sección sur, el edificio se compone de una plataforma sobre la cual se construyeron recintos; uno incluye un altar grabado con friso (Figs. 7a, 9, 10). El frontis del edificio (25 metros de largo), dotado al oeste de un acceso lateral, está orientado hacia un espacio abierto (¿plaza, patio?). Una estructura en forma de prisma (¿un altar?) conformada por un relleno compacto cubierto de una capa fina de enlucido delimita su esquina sur-este (Fig. 11h). El espacio abierto corresponde al estrato de arcilla natural acondicionada en gradas en ciertos sectores y en pendiente en otros.

En el estado actual de las excavaciones, parece difícil entender la articulación entre las secciones norte y sur del edificio sin desmontar las estructuras de la etapa posterior. Sin embargo, en el flanco oeste del montículo, la excavación de un recinto ${ }^{2}$ develó la matriz de una tumba de forma circular, coronada por una estructura (¿pilares?) con huellas de ocre. Esta tumba excavada en un momento 

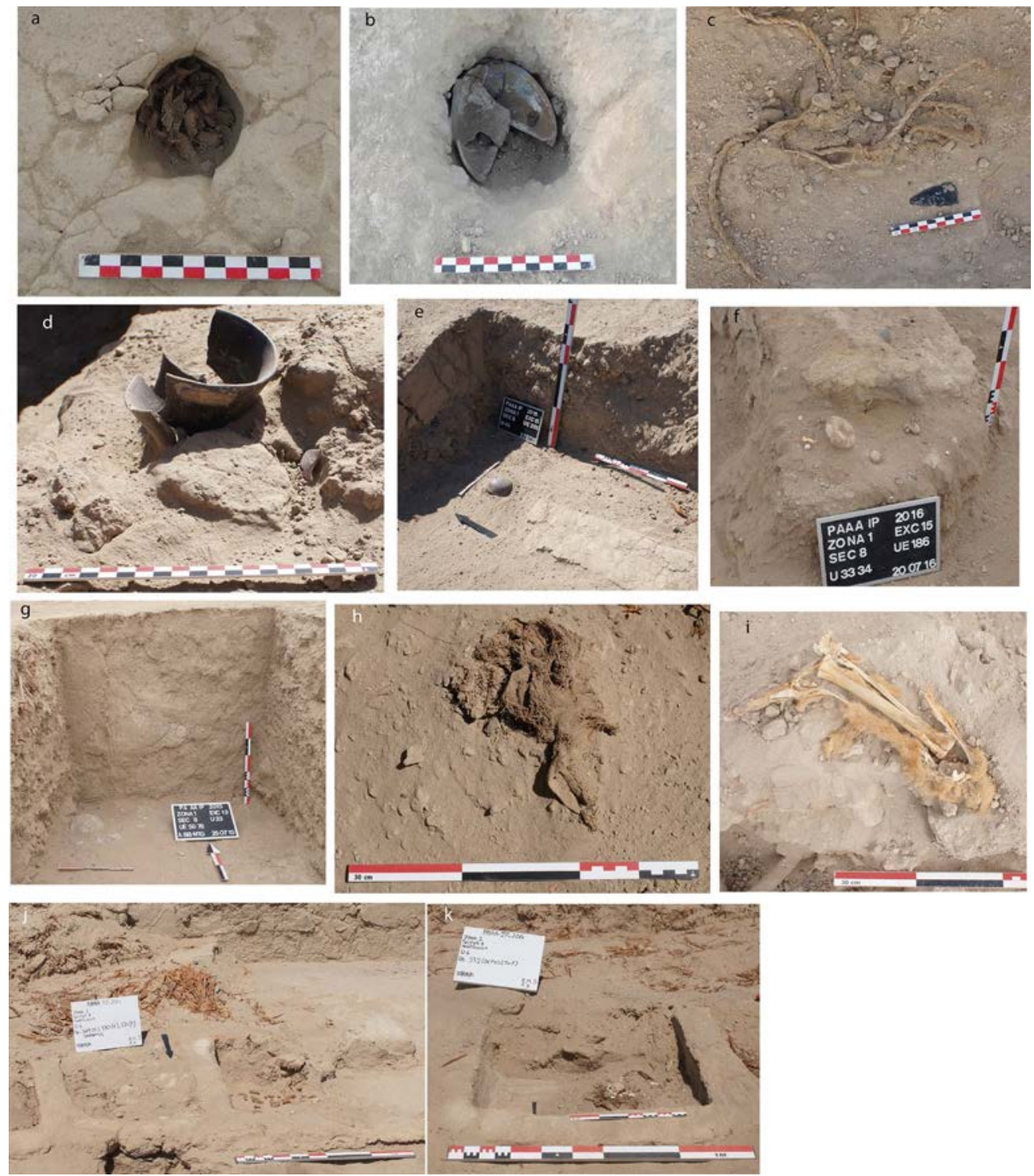

Figura 5. Ofrendas halladas sobre los pisos, en hoyos y en los rellenos, PAAA IP temporadas 2014-2016 (fotos: A. Bachir Bacha).

dado durante el uso del primer edificio parece haber sido vaciada, y, luego, rellenada con ceniza y tierra fina al momento de la construcción de la sala hundida del segundo edificio. Antes de enterrar las primeras construcciones, se depositaron varias ofrendas y se celebraron ceremonias.

Sobre el piso del Corral 4, se halló una concentración de corontas de maíz (Fig. 5j), cubiertas por un relleno que contenía un textil bordado polícromo e hilos blancos y de colores (verde y naranja). Por su parte, el relleno que cubría el Corral 5 develó un depósito de motas de algodón marrón y blanco, restos de textiles llanos (fragmentos de mortajas), hilos de color (verde, amarillo, celeste y marón), cabello, un fragmento de mate, así como fragmentos de cerámica doméstica. Sobre el piso del Corral 6, yacía una concentración de plumas, hueso, tela llana y coprolitos. Por su parte, en el piso del Corral 8, se develó un conjunto compuesto de tejido de fibra de camélido decorado, restos de textiles (mortajas) de algodón, hilos, plumas, cabello, mate inciso, restos malacológicos y 


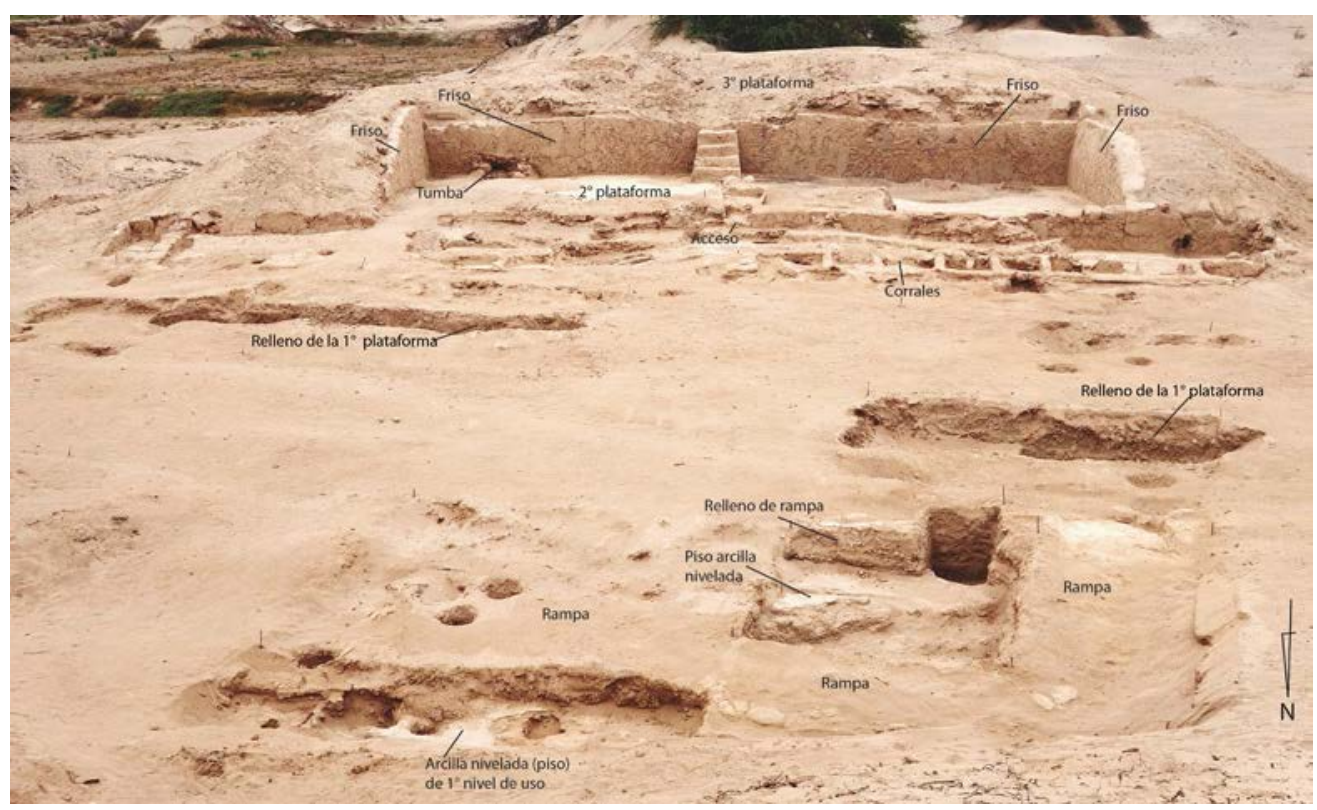

Figura 6. Excavación del Edificio de los Frisos, sección norte, PAAA IP temporada 2014 (foto: A. Bachir Bacha).

un fragmento de cerámica con decoración incisa y pintura poscocción (Ocucaje 9). En el piso del Corral 9, yacía la olla que contenía los restos de coprolitos de cuyes.

A lo largo del muro central del atrio grabado con frisos, se hallaron los vestigios de tres grandes recipientes, colocados en hoyos cavados en el piso. El colapso de sus cuerpos se debió al peso del relleno, o a un ritual de sacrificio de objetos en el cual se rompieron estos recipientes. La excavación del atrio también descubrió una gruesa capa de ceniza que cubría gran parte del área sur- oeste del piso, testigo de un evento de combustión. Hacia el norte, frente a la escalera, se encontraron cuentas en conchas marinas y un fragmento de cerámica polícroma (Ocucaje 8) decorada con motivos de cuadrados concéntricos. Estos eventos indudablemente están vinculados al enterramiento del edificio, pero también al de un difunto de alto rango, sepultado en la tumba adosada al muro (Figs. 6, 8).

En la sección sur del edificio, antes de cubrir los recintos, en el piso del recinto del altar con friso grabado, se cavaron hoyos (cuatro a 15 centímetros de diámetro), en los que se depositaron cáscaras de maní (Arachis hypogaea), capullo de algodón, hojas de pacae (Inga sp.), semillas, trozos de tiza y conchas (Figs. 5a, 5b). Junto al muro del altar, se hallaron hojas de pacae, mientras que sobre el piso del recinto oeste se descubrieron cáscaras de maní.

Antes de cubrir el frontis sur del primer edificio, se colocó sobre el piso un cúmulo de piedra (Fig. 5g), de caracoles de lomas, algas y fragmentos de cerámica (Ocucaje 9-10). Hacia el oeste, sobre este mismo piso, se encontró el cuello de un cántaro (Ocucaje 9) restos de erizos, algunos de ellos conservaban todavía sus espinas (Fig. 5d, 5f). En el relleno que cubre este piso, se halló una figurina de piedra (Fig. 12k), que representaría un felino; una punta de obsidiana (Fig. 5c); un fragmento de ¿figurina? de arcilla cruda; así como restos de magnesio.

En la sección oeste, cerrando las estructuras del primer edificio, se colocó boca abajo un cuenco con decoración negativa (Ocucaje 9-10) en el relleno que cubre el extremo norte del frontis del edificio (Fig. 5e), mientras que un fragmento de arcilla cruda (¿̨resto de una figurina?) se depositó en los rellenos que cubren el extremo sur.

Sobre la base de los datos expuestos, las estructuras del primer edificio corresponden a la fase 3 de la secuencia del sitio, tiempo en el cual la arquitectura de Ánimas Altas se monumentaliza, 


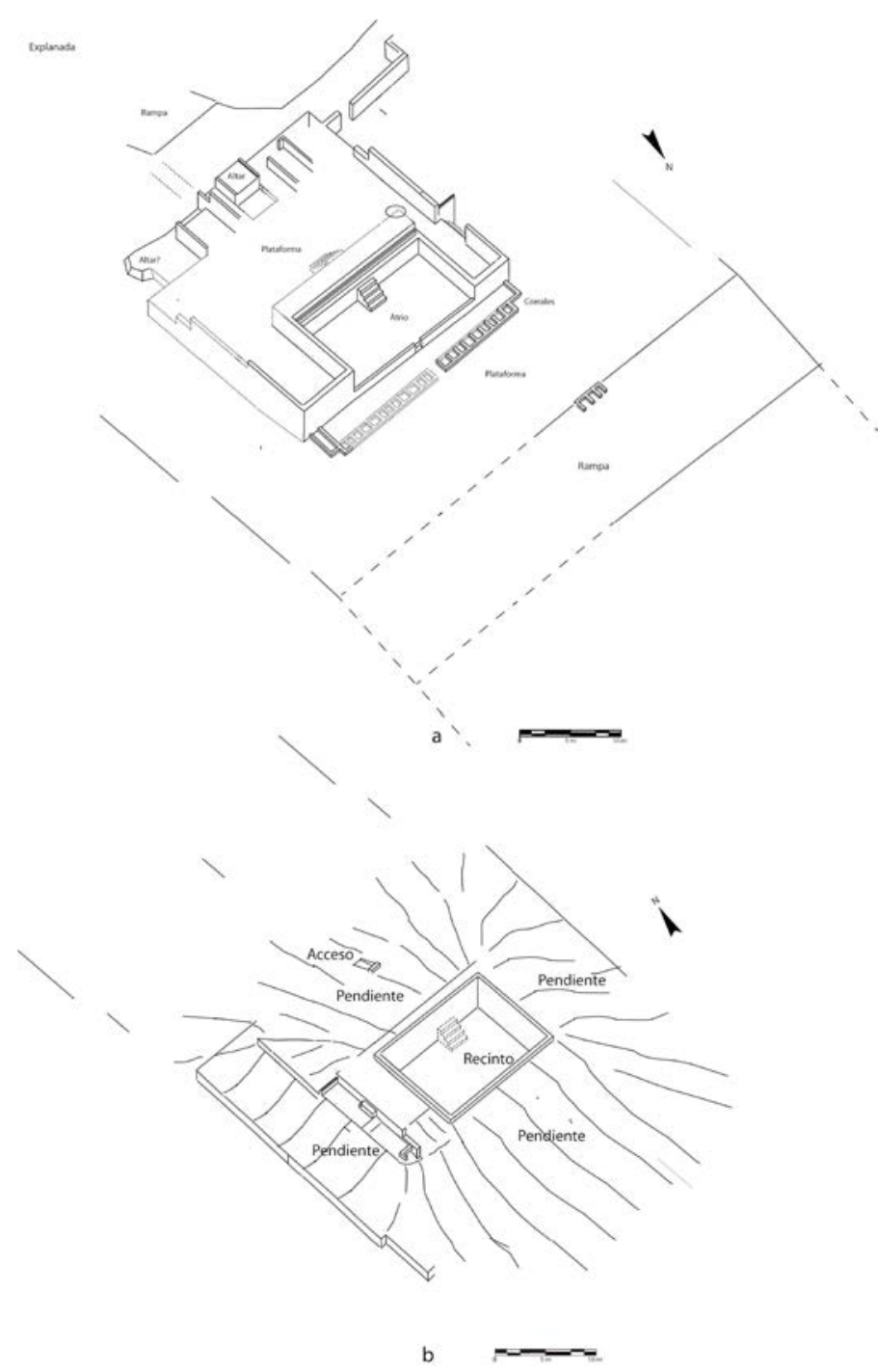

Figura 7. Reconstitución isométrica del Edificio de los Frisos: a. Edificio 1; b. Edificio 2 (elaboración del dibujo: O. D. Llanos J. y A. Bachir Bacha).

mientras que aquella de Ánimas Bajas se estanca. En términos de tipología, la cerámica asociada a esta fase es Ocucaje 9-10, raramente Ocucaje 8. Los textiles son comparables a aquellos asignados a Paracas Cavernas, mientras que los frisos presentan íconos paracas tardío (Ocucaje 9/10), pero también motivos con rasgos cupisnique-chavín.

6.1.3. Edificio 2. Los rellenos dispuestos en pendiente, compactos y densos, compuestos esencialmente de tierra y terrones, y que sellan el primer edificio, forman los volúmenes del segundo. El nuevo edificio es una pirámide circunscrita por un muro revelado por las excavaciones en la sección oeste del montículo (Fig. 7b).

La cima del nuevo edificio incluye un recinto hundido, erigido sobre el piso de la plataforma anterior y con medidas estimadas de 20 metros por ocho metros (Fig. 11f). La cara interior de una de sus paredes tiene un friso de barro modelado que representa una silueta escalonada de seis 

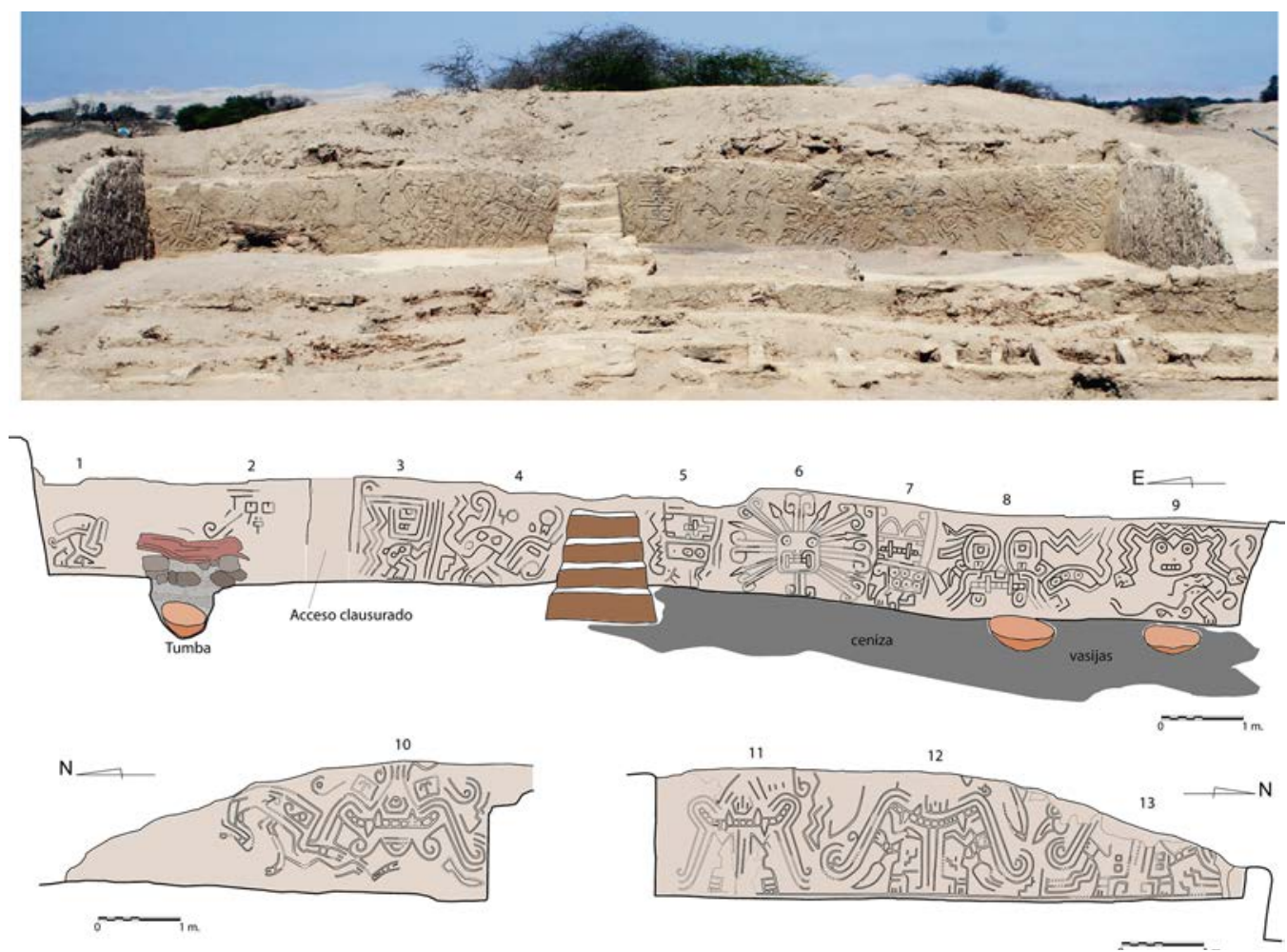

Figura 8. Excavación del Edificio de los Frisos: a. atrio con paredes grabadas de frisos; $b$. detalles de la iconografia de los frisos, PAAA IP temporada 2014 (foto: A. Bachir Bacha; elaboración del dibujo: O. D. Llanos J. y A. Bachir Bacha).

gradas (Fig. 13). En el estado actual de los descubrimientos, no se conoce cuál es el acceso a este espacio, a menos que la ausencia de la entrada sugiera que se accedía desde la cima de la plataforma que lo rodea. El nuevo proyecto arquitectónico integra también una pequeña terraza dotada de un altar y un volumen arquitectónico escalonado, acondicionados en el flanco oeste del nuevo edificio (Fig. 11c). Asimismo, en el flanco norte, precisamente sobre el relleno que cubrió el antiguo acceso que conduce al atrio, se construyó otro acceso dotado de tres peldaños.

6.1.4. Remodelaciones del Edificio 2: Etapas constructivas 3 y 4. En un momento dado, el recinto hundido del segundo edificio fue cubierto con un nuevo relleno para elevar encima otro recinto (Etapa constructiva 3) igualmente hundido, de menor tamaño, con lo cual aumentó la altura de la pirámide pero cerrando más el espacio. La terraza del flanco oeste también se sella parcialmente y se acondiciona un muro en forma de «L» (Fig. 14a). La última etapa de remodelación (Etapa constructiva 4) corresponde a la construcción de un tercer recinto de dimensiones aún más reducidas que los precedentes (Fig. 14b). Es muy probable que el último espacio haya funcionado por un corto tiempo antes del sello del edificio.

El segundo edificio piramidal pertenece a la fase 4 del sitio, momento en que los edificios de Ánimas Altas fueron remodelados. Las plataformas piramidales se cubrieron para dar lugar a grandes rampas que permitían el acceso a las cimas de la pirámide, sobre las cuales se construyeron, recintos o bien altares. Lastimosamente, estas estructuras han sido disturbadas por la acción del pillaje y por el paso del tiempo. Los materiales asociados (cerámica, textil y otros artefactos) a los contextos no difieren de aquellos de la fase anterior. El diseño de los edificios cambia y toma la forma de pirámides truncadas dotadas de terrazas. 

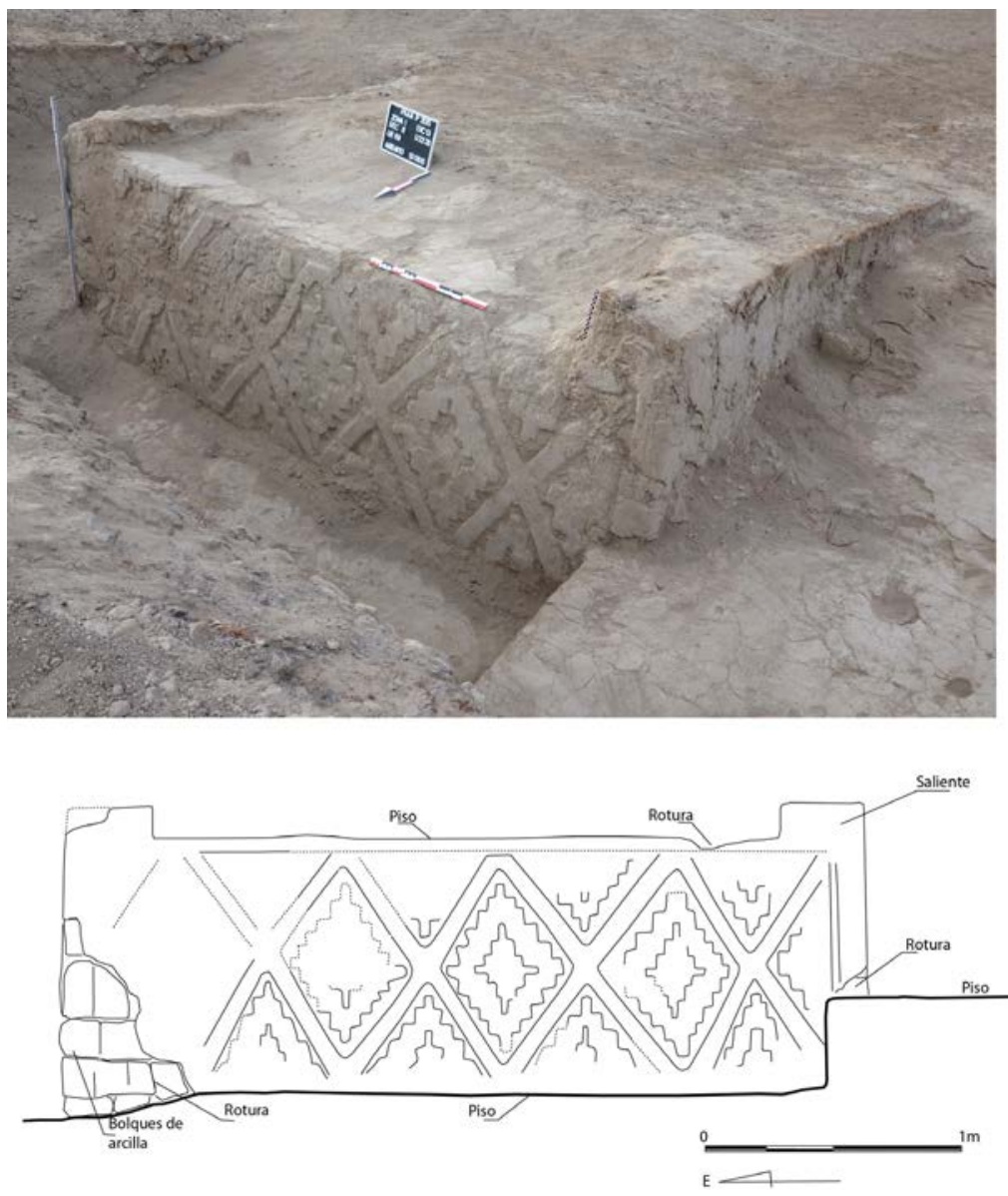

Figura 9. Excavación del Edificio de los Frisos, sección sur, muro del altar grabado con friso, PAAA IP temporada 2015 (foto: A. Bachir Bacha; elaboración del dibujo: O. D. Llanos J. y A. Bachir Bacha).

6.1.5. Sello del edificio. Las huellas del sello del segundo edificio se observan en el enterramiento del último recinto hundido y de las estructuras del flanco oeste bajo una capa de relleno (60 centímetros de grosor). De este último evento resulta una estructura piramidal cuya base es de 35 metros (E-O) por 60 (NS) y con una altura estimada de cinco metros.

Las evidencias dejadas por un evento de preparación y consumo de alimentos ligado al sello del frontis oeste corresponden a material malacológico: macha (Mesodesma donacium), choros azules, lapas (Patela vulgata), caracoles turbantes (Tegula atra), erizos y caracoles de lomas, restos vegetales, manos de batanes, restos de huesos humanos (fémur, tibia, pelvis), un artefacto en hueso de camélido, un figurina de arcilla cruda; todo esto fue hallado en el piso. Una cantidad importante de ceniza y coprolitos humanos fueron también registrados en el relleno que cubre el piso (Fig. 15).

El relleno que cubre el último recinto del edificio ha develado un conjunto de pequeños cantos rodados pulidos que constituirían o un material de molienda, o bien proyectiles de hondas usadas para la guerra y la caza. Estaban asociados a una figurina tallada en hueso de camélido (Fig. 12J), así como a fragmentos de cerámica (Ocucaje 9-10, un fragmento Ocucaje 8). 


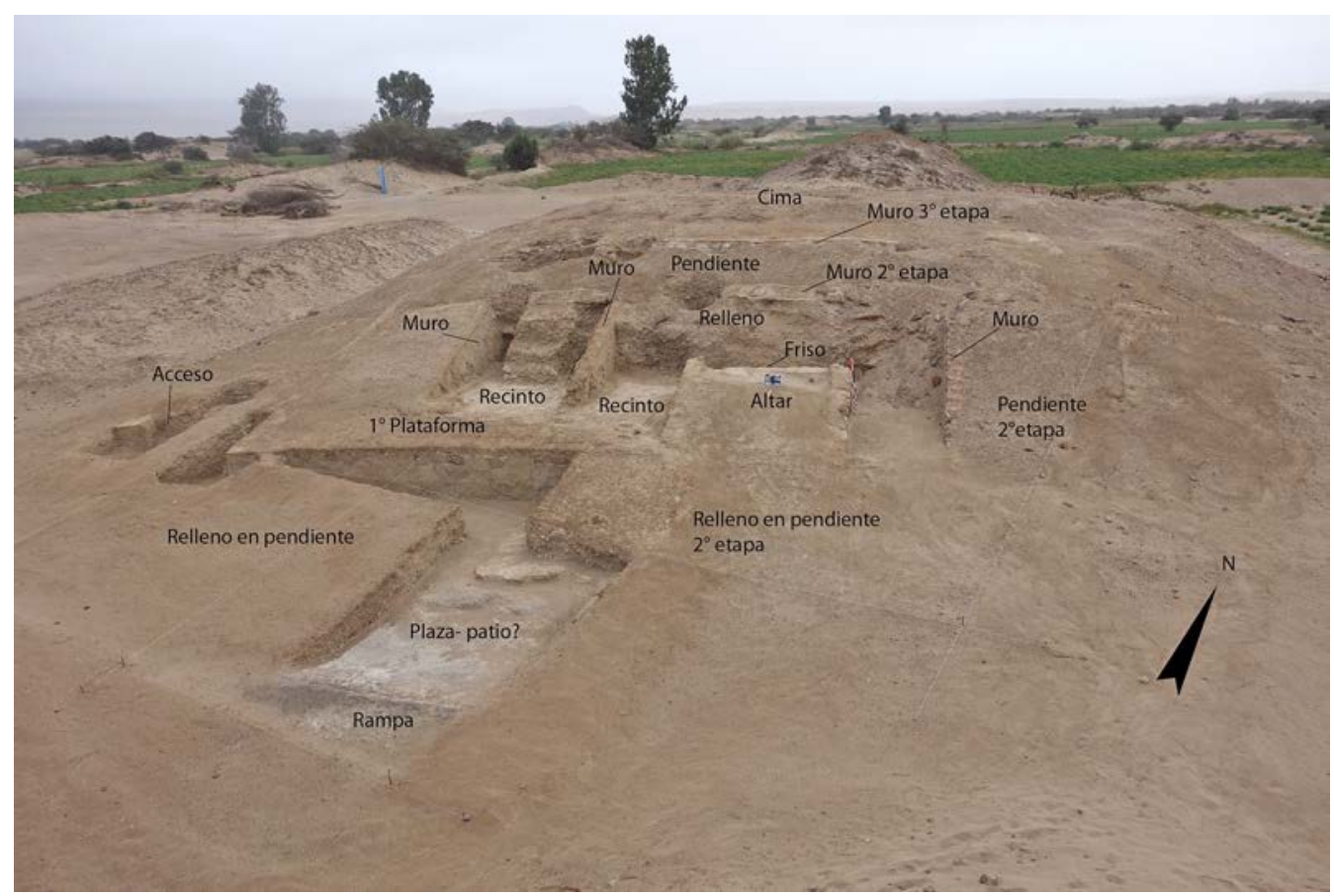

Figura 10. Excavación del Edificio de los Frisos, sección sur, PAAA IP temporada 2015 (foto: A. Bachir Bacha).

\subsection{Materiales y prácticas constructivas}

La arquitectura registrada en el Edificio de los Frisos difiere levemente de aquella de otras estructuras (Edificio de las Banquetas, Edificio de las Dunas) por la ausencia de grandes muros perimétricos de contención del relleno. Sin embargo, los muros de las construcciones a semejanza de los otros edificios emplean bloques de arcilla sedimentaria de tamaños y formas distintos, con tendencia hacia una forma semirrectangular (Figs. 11e, 11g).

Los muros del atrio decorados con frisos no superan más de 1,50 metros de alto ${ }^{3}$ (Figs. 6, 8). Sus bloques provienen de diferentes canteras; sus características y dimensiones son variables, así como sus colores (beige, gris, gris verdoso), y su alineamiento presenta irregularidades. Para unir los bloques, los constructores optaron por un mortero compuesto de arcilla mezclada con una cantidad de paja más o menos regular. En ciertas partes, se incorporaron gruesos manojos de paja entre los bloques. Los muros fueron uniformizados con una argamasa a base de arcilla, arena fina y paja. En algunas partes, este primer enlucido es tan denso y sólido que se mantuvo en las secciones que han perdido el mortero, a partir de lo cual forman una suerte de trama o tejido que unifica y consolida el muro. Una segunda capa de enlucido, más elaborada, compuesta de arcilla, arena fina, arenilla y paja, cubre el primero. Este enlucido contiene más arena que paja. Los frisos fueron grabados sobre estas dos capas, lo que les da un aspecto de bajo relieve. El trazo del grabado se ejecutó sobre un soporte más o menos húmedo, quizás con dos instrumentos, uno de madera puntiaguda y otro de piedra pulida con punta más redonda. Una tercera capa, compuesta de barro a base de arena y paja fina de muy buen acabado, sella el friso. Cabe seńalar que la cara interna del muro sin acabado se apoya sobre el relleno de la plataforma.

Los once pequeños corrales construidos sobre el piso de la terraza se componen de muretes que forman celdas ${ }^{4}$ o espacios reticulares alineados de este a oeste (Figs. 6, 8). Los muretes se construyeron con terrones unidos por una argamasa a base de arcilla revestida por un fino enlucido. 

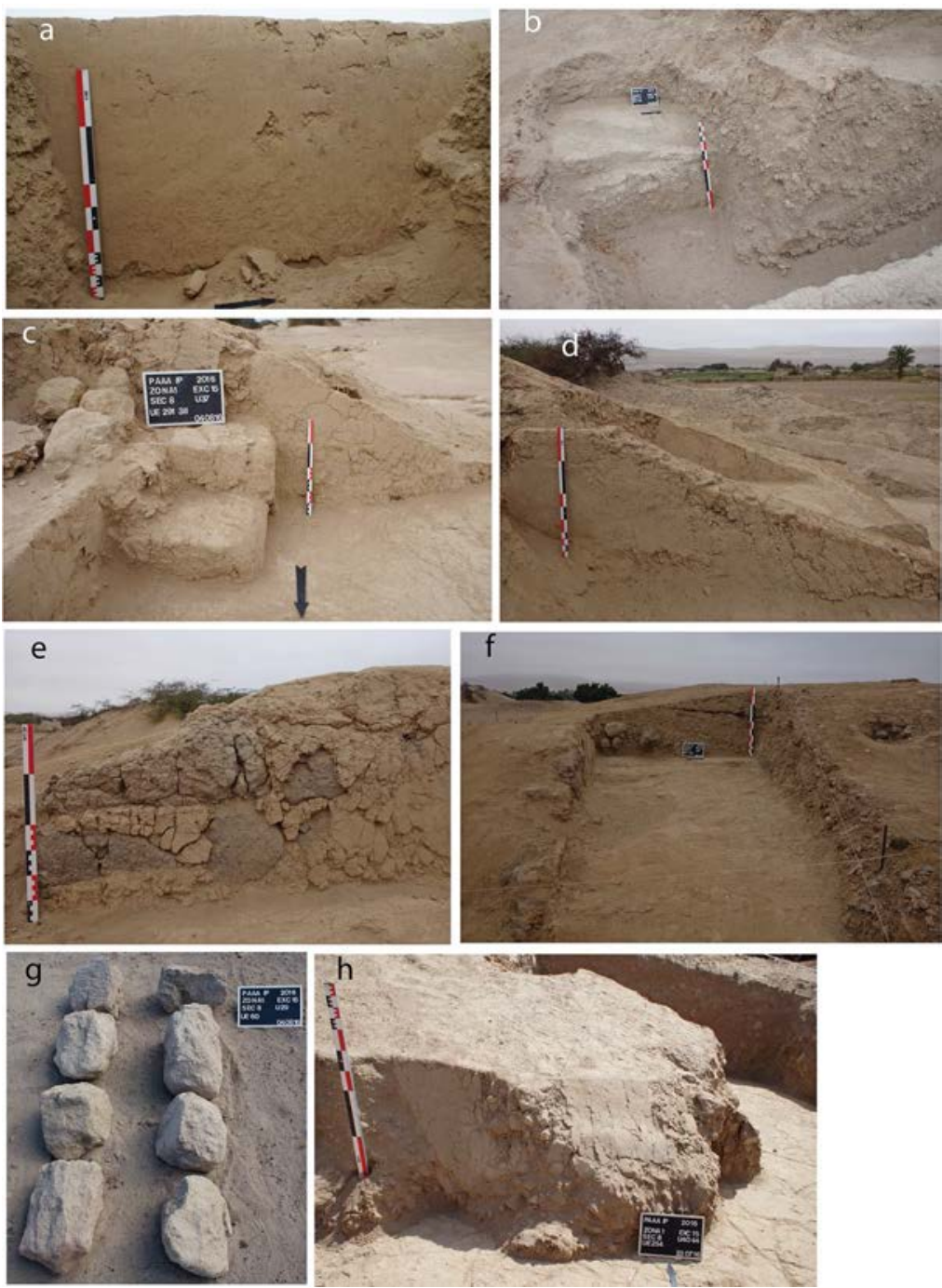

Figura 11. Detalles de elementos arquitectónicos del Edificio de los Frisos, PAAA IP temporadas 2015-2016 (fotos: A. Bachir Bacha).

El muro del altar ${ }^{5}$ con friso, construido con seis hiladas de bloques de arcilla sedimentaria, presenta dos pequeños salientes en cada extremo superior (Fig. 9). Las argamasas difieren con las descritas anteriormente por las fórmulas arcillosas del mortero y de los enlucidos. Los bloques de arcilla sedimentaria unidos con un mortero de consistencia rústica (arcilla, paja, muy poca arena) fueron revestidos con dos capas de enlucido. La primera a base de arcilla, a la cual se agregó mucha paja y poca arenilla, consolida el muro y compensa la fragilidad del mortero. La segunda contiene más arena y paja, lo cual da un aspecto granuloso, arenoso y una envoltura frágil al friso. A juzgar por la huellas de dedos, la última capa de enlucido fue alisada a mano. El friso fue grabado sobre el enlucido húmedo y, luego, algunas partes de la superficie fueran retiradas. La combinación de estas dos técnicas (incisión y excisión) da un aspecto bajo relieve al friso. Asimismo, el «artista» se encargó de eliminar el trazo angular de los motivos, redondeándolo con un dedo probablemente mojado. Este gesto se adivina pasando el dedo por las huellas que dejó. 

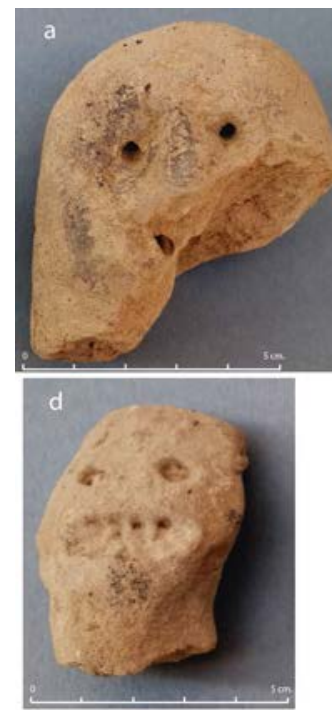

g
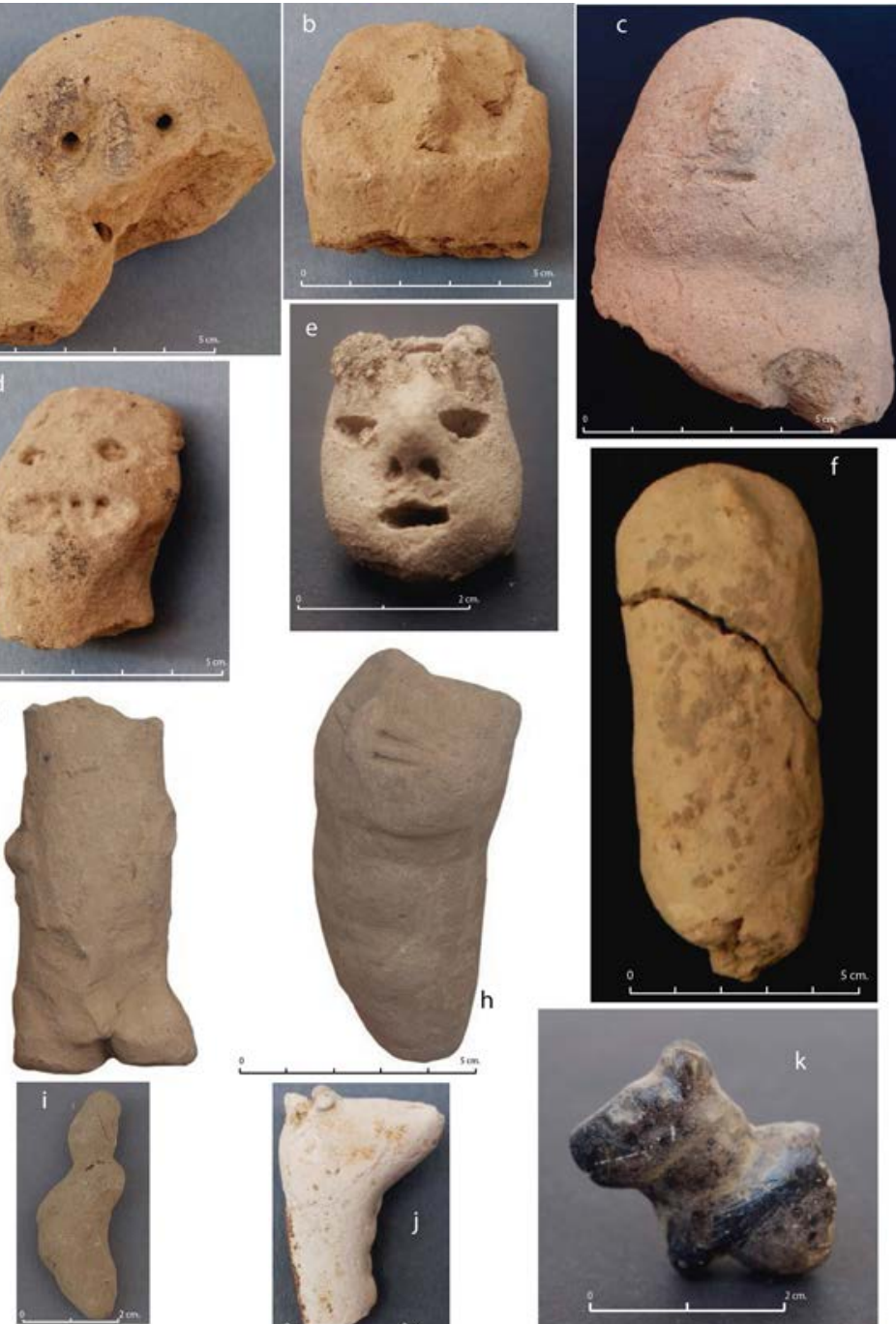
.
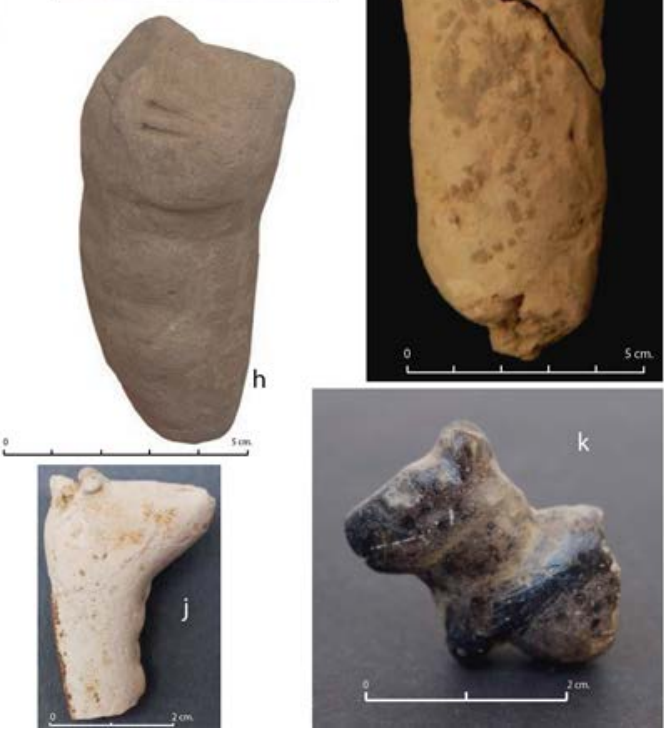

Figura 12. Figurinas halladas en el Edificio de los Frisos y otros sectores de Ánimas Altas (fotos: A. Bachir Bacha).

El muro del friso ${ }^{6}$ del recinto hundido del segundo edificio se construyó con bloques de arcilla sedimentaria, cuya disposición — de abajo hacia arriba y ligeramente desfasada hacia el sur — configura una forma escalonada. Una vez que el muro fue enlucido con barro, se logra un motivo escalonado de seis bandas con esquinas ondulantes. Aquí también se observa el deseo de redondear los ángulos del motivo empleado las mismas técnicas descritas anteriormente (Fig. 13).

En lo que se refiere a los rellenos, existe un contraste entre aquellos del primer y segundo edificio. Los primeros, de poca altura, semicompactos, edificados con capas de tierra y terrones, intercalados por estratos vegetales, están cargados con material arqueológico incluida numerosas ofrendas. En cuanto a los segundos, compactos y gruesos (dos metros de grosor), construidos con terrones, incluidos por partes grandes bloques de arcilla sedimentaria y recubiertos por capas vegetales (chala de maíz), presentan ofrendas pero muy poco material arqueológico disperso, en particular, en la sección sur del montículo (Figs. 11b, f). 


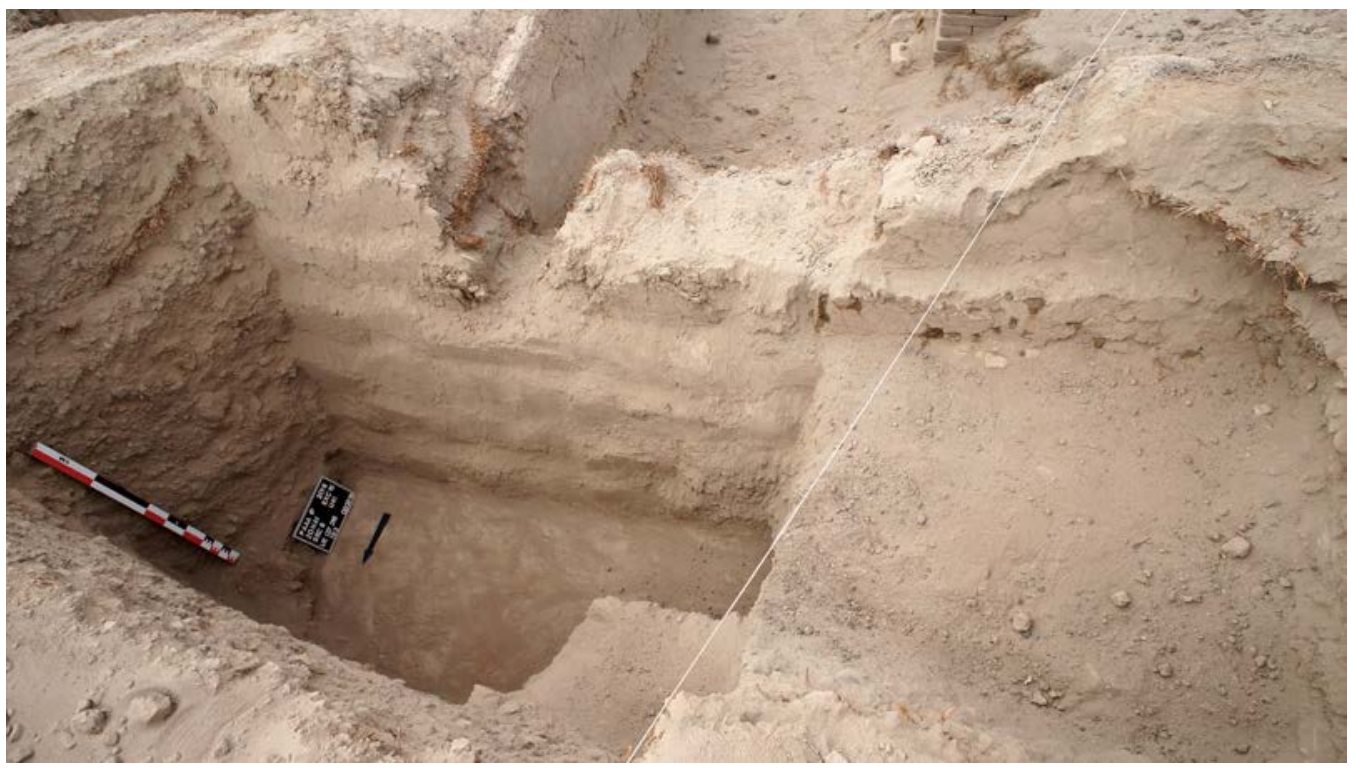

Figura 13. Friso del recinto hundido, PAAA IP temporada 2016 (foto: A. Bachir Bacha).

A diferencia del proceso de construcción del primer edificio, cuyas plataformas fueron edificadas con muros periféricos de contención de rellenos, en el nuevo edificio (Etapa 2), la situación se invierte. Los rellenos en pendiente muy compactos cubren las estructuras originales y sostienen los muros de los recintos hundidos. Estos últimos presentan una cara revestida de enlucido fino, lo cual revela por partes huellas de pintura roja o marrón oscuro (Fig. 11a), mientras que sus caras interiores sin acabado se apoyan sobre los rellenos.

\subsection{Textiles}

En comparación con otros sectores excavados, pocos fragmentos de textiles en fibra de algodón y alguno en fibra de camélido fueron exhumados en los rellenos (rampa, terraza, corrales). Entre los fragmentos, se pudo distinguir partes de envoltorios de fardos, redes, una bolsa en fibra de algodón y restos de una cinta en fibra de camélido. Las piezas identificadas son tejidos llanos y gasa. En la decoración, se distinguen los tejidos llanos listados, estructurales, bordados y teñidos.

Los tejidos llanos son de fibra de algodón en tonos naturales blanco, beige o marrón; la mayoría pertenecen a mortajas. A estos se suman restos de telas de algodón bordadas. Los bordados con fibra de algodón presentan motivos listados que combinan los colores verde y rojo (Fig. 16c); otros muestran listados de color marrón y un espécimen representa un personaje con rasgos felínicos (Fig. 16a). Los bordados con fibras de camélido ostentan varios colores (rojo, verde, amarillo negro, marrón y naranja) y sus diseños evocan generalmente personajes con una boca en "V》" (Figs. 17a, 17b). El textil hallado en el Corral 4 representa a un personaje estilizado en posición de vuelo (Fig. 16b). La cinta en fibra de camélido y decoración estructural que combina varios colores (marrón oscuro, verde, naranja claro y naranja rojizo) exhibe una serpiente.

\subsection{Cerámica}

En el estado actual de las investigaciones, la cerámica recuperada en el Edificio de los Frisos no varía mucho de aquella registrada en otros sectores. A partir de sus características morfológicas, tecnológicas y decorativas, se registraron ocho tipos de vasija: ollas de cuello corto cóncavo, cuencos con 

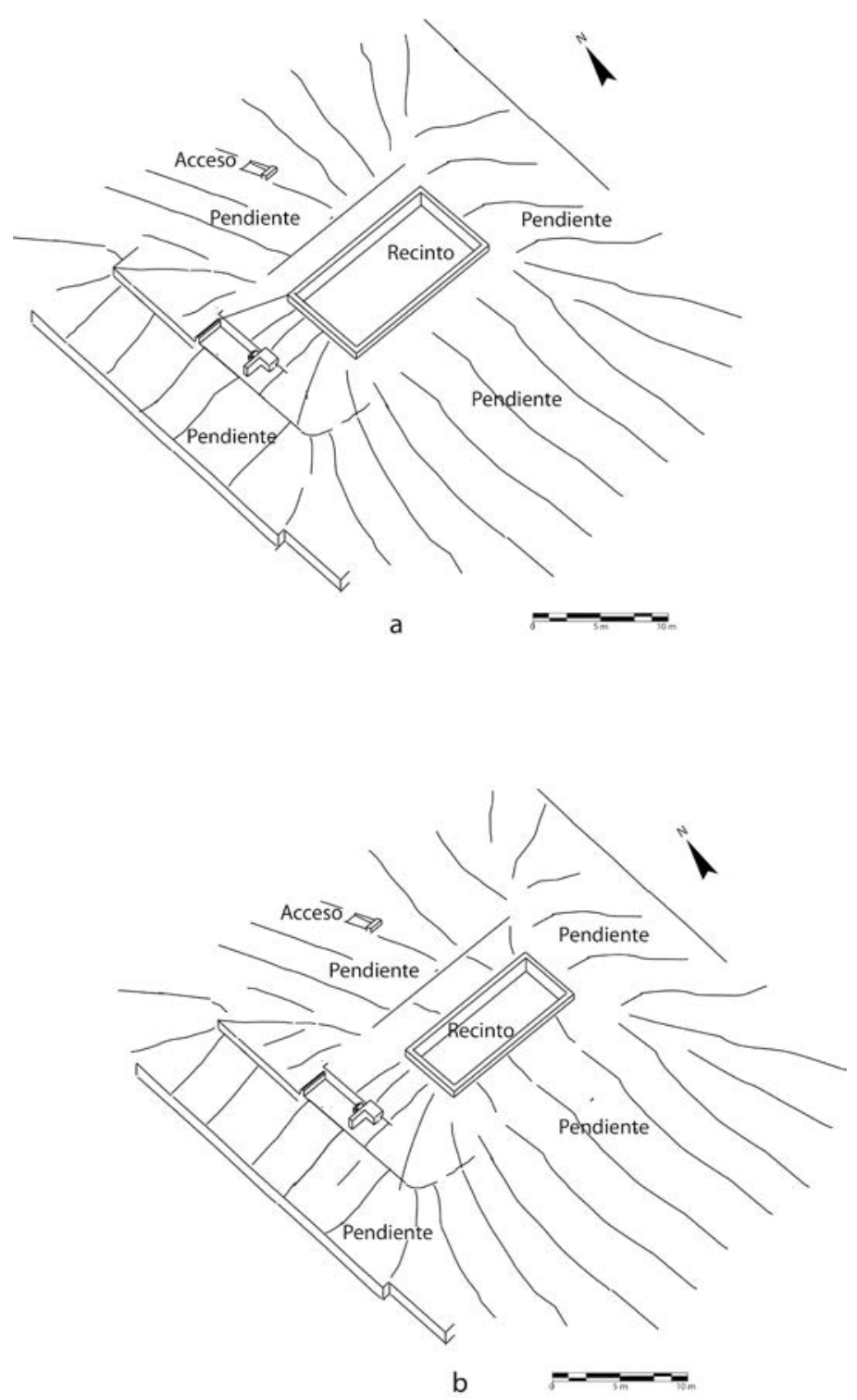

Figura 14. Reconstitución isométrica del Edificio de los Frisos y remodelaciones del Edificio 2: a. etapa constructiva 3; b. etapa constructiva 4.

decoración negativa, cuencos con decoración incisa y pintura poscocción, cuencos con decoración incisa, ollas sin cuello con reborde, algunos cántaros y botellas. Asimismo, la cerámica analizada corresponde a recipientes destinados a la cocción, transporte, reparto y consumo de alimentos (Figs. 18, 19).

Los recipientes presentan un tratamiento de superficies externas e internas más o menos elaborado que consiste mayormente en un pulido burdo con piedra, pero se observó también un pulido fino, un alisado burdo con los dedos o con un textil y otro fino. Otros recipientes muestran un engobe de color marrón rojizo (ollas y cuencos) o bien gris (cuencos). La atmósfera de cocción dominante es de tipo oxidante, aunque existe cerámica cocida en atmósfera reductora, así como en atmósfera reductora y oxidante. El análisis preliminar del material cerámico permitió también 


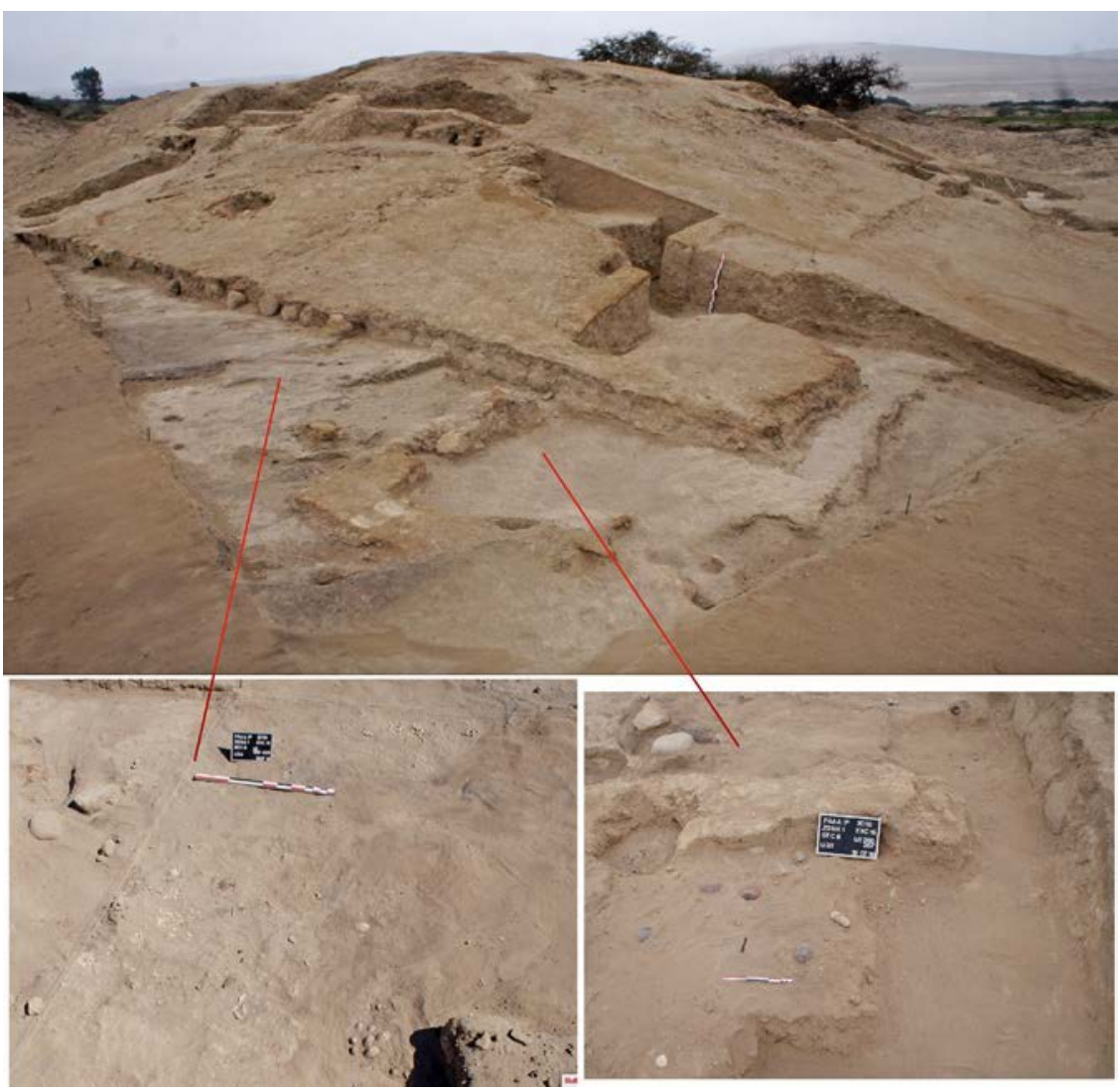

Figura 15. Excavación del Edificio de los Frisos, sección oeste, PAAA IP temporada 2016 (fotos: A. Bachir Bacha).

identificar cinco alfares. Estos indican la existencia de talleres de vasijas de producción y almacenamiento relativamente homogéneos (un alfar) frente a talleres diversificados para el caso de vasijas de reparto y consumo (cuatro alfares). ${ }^{7}$

Los cuencos están decorados con escalonados, pirámides, rombos, serpientes, felinos o la efigie del Ser Oculado (Ocucaje 9-10), logrados con la técnica de incisión y pintura resinosa poscocción, utilizando colores rojos, anaranjados y amarillo verdoso sobe un fondo negro o marrón oscuro (Figs. $20 \mathrm{a}-\mathrm{m}, 21 \mathrm{a}$ ). Las mismas representaciones logradas con la técnica de la incisión aparecen en los cuencos monócromos de superficies naranja, marrón o gris oscuro. A estos se suman motivos como círculos concéntricos alineados, semicírculos alineados y diseños rayadores, ausentes en la cerámica polícroma. La cerámica decorada mediante la técnica del negativo (Ocucaje 9-10) suele tener fondo naranja con diseños marrón oscuro, gris oscuro y negro, o bien fondo marrón oscuro con diseños naranjas. Entre los motivos dominantes en esta cerámica, se cuentan los listados o bandas verticales representadas en las paredes externas de los cuencos (Fig. 21d). La decoración de las paredes interiores se encuentra solo en los bordes, en forma de símbolos en « $\mathrm{V}$ », aspas o una banda horizontal. Algunos fragmentos de ollas de cuello corto presentan círculos en sus paredes externas (Fig. 21b, 21c, 21e).

Hay que recordar que las excavaciones del Edificio de los Frisos no evidenciaron en estratigrafía la sucesión de los «subestilos» o «fases» Ocucaje 8, 9 y 10. En este sector, las excavaciones revelaron solamente dos fragmentos de cerámica Ocucaje 8, uno hallado en el relleno que cubrió al atrio (Fig. 20a) y el otro en el relleno que cubre el último recinto hundido (Fig. 20b). Sin embargo, la estratigrafía de las excavaciones realizadas en el Edificio de las Dunas, ubicado en la sección sur 


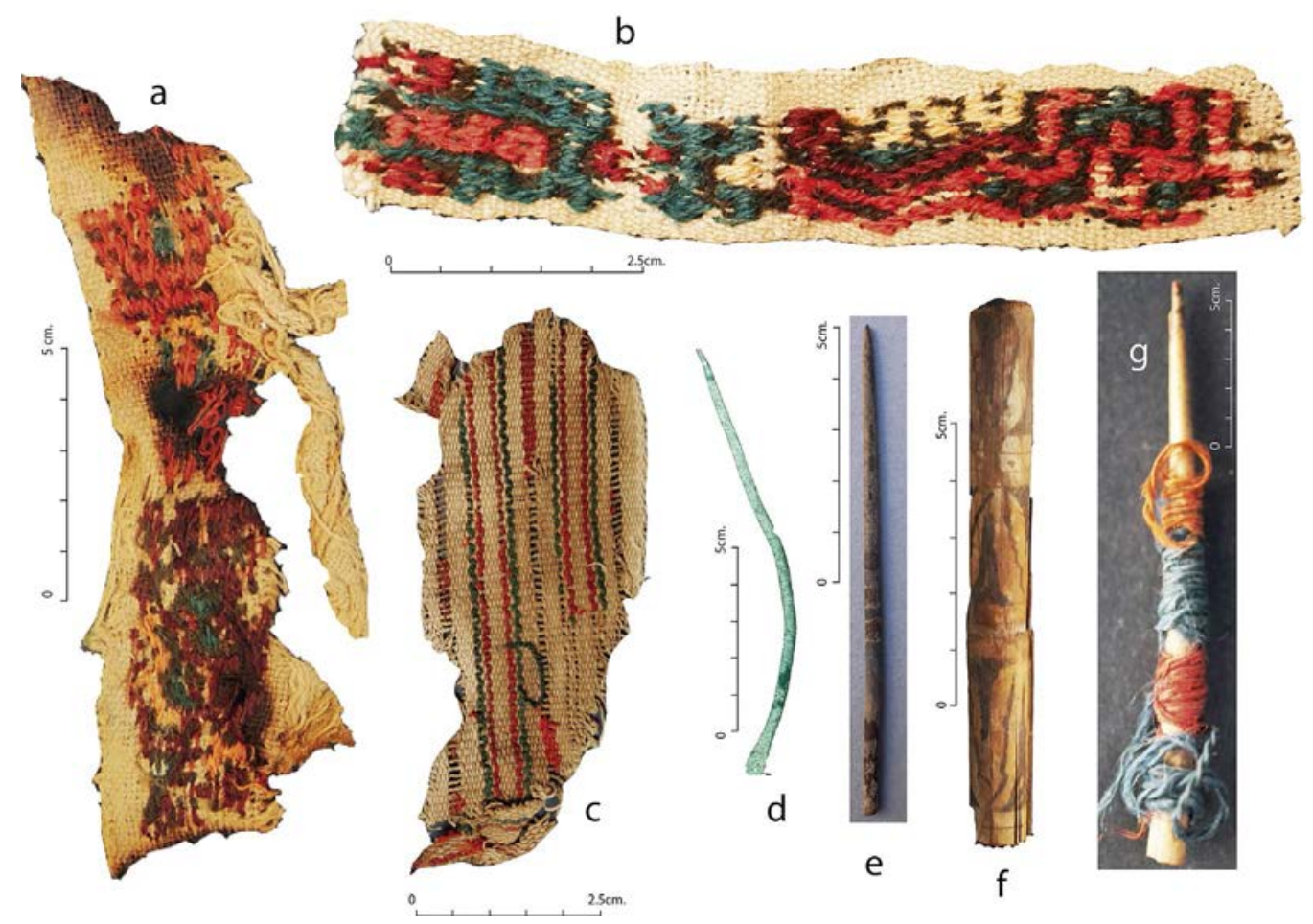

Figura 16. Textiles y herramienta para su manufactura hallados en el Edificio de los Frisos, PAAA IP temporadas 2014-2016 (fotos: A. Bachir Bacha).

del sitio (Ánimas Bajas), permite confirmar que, en este sector, la cerámica ocucaje 8 precede a la ocucaje 9 (Bachir Bacha y Llanos 2013).

\subsection{Otros materiales y artefactos}

$\mathrm{Al}$ igual que en otros sectores excavados, en los rellenos constructivos y aquellos que cubrieron las estructuras de los flancos norte y oeste del Edificio de los Frisos, se recuperaron restos botánicos, faunísticos, materias primas y abundantes restos malacológicos. Estos vestigios testimonian del manejo de una economía diversificada: agricultura, pesca, marisqueo e intercambios a corta y larga distancia, sin perder de vista la crianza de cuyes y de camélidos. De igual manera, las excavaciones del Edificio de los Frisos revelaron la presencia de objetos relacionados con la producción de cerámica, textiles, figurinas, cuentas en concha marina e industria lítica. Los materiales recuperados no se limitan a piezas acabadas, pues existen también materias primas, instrumentos de confección (Fig. 16d, 16e, 16f, 16g) y desechos que evidencian cadenas productivas completas, incluso para los textiles en fibra de camélido, ${ }^{8}$ tal como se ha detallado en publicaciones previas que hacen referencia a otros sectores excavados (Bachir Bacha y Llanos 2011: 215; Bachir Bacha y Llanos 2013: 194-196, figs. 24 y 25). Además, entre los materiales del Edificio de los Frisos, destacan figurinas, objetos no tan comunes en la costa sur. Se trata de piezas modeladas en arcilla cruda, en general, con formas antropomorfas o bien zoomorfas (Fig. 12a-i). Por su parte, la industria lítica se menciona poco en la literatura, pero está presente como objetos de forma más o menos esférica que se habrían utilizado como proyectiles de las hondas empleadas en la caza y en la guerra. 

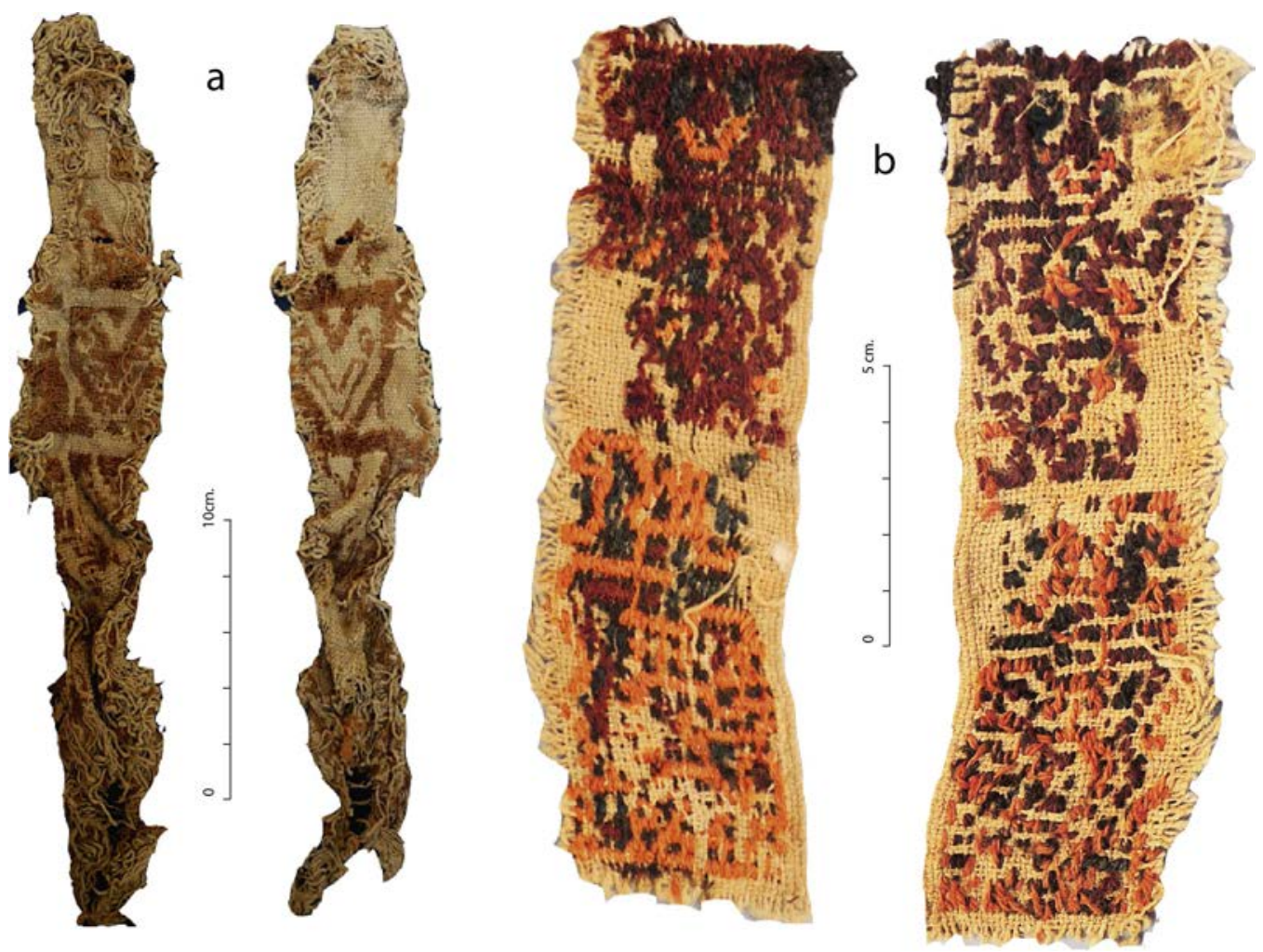

Figura 17. Textiles hallados en el Edificio de los Frisos (fotos: A. Bachir Bacha).

Finalmente, destacan la presencia de materias primas que permitieron el desarrollo de una manufactura cerámica de gran variedad tecnológica y estilística, que, sin duda, hizo notable el aura político-religiosa del sitio, y de la zona de Callango a escala regional y supra regional (Bachir Bacha y Llanos 2013; Bachir Bacha e.p.). De hecho, arcilla, limonita y pigmentos minerales - como ocre, óxido de magnesio, óxido de hierro (hematita), tiza y fosfatos provenientes de las cadenas de cerros visibles desde Ánimas considerados localmente como huacas - han sido hallados bajo forma de ofrendas o bien dispersos en los rellenos del Edificio de los Frisos (Fig. 22).

\section{La función del Edificio de los Frisos}

Poca duda cabe sobre la función político-religiosa del Edificio de los Frisos y otros edificios de Ánimas (Edificio de las Banquetas, Edificio de las Dunas), en los que se realizaron ceremonias, se depositaron ofrendas, se sepultaron miembros de la élite y se veneraron ancestros. Su organización espacial, diseño, acabado de su arquitectura y sus frisos lo distinguen de las plataformas laterales, y de las otras estructuras de carácter doméstico y/o de producción registradas en la zona sur de Ánimas Altas. Sin embargo, el Edificio de los Frisos está vinculado con la vida diaria del sitio, como lo demuestran las huellas de la cultura material presentes en los rellenos de su construcción y enterramiento mencionados líneas arriba. Además, las áreas de producción y/o de actividades domésticas (Montículo 30, D1, Plaza 1) identificadas en la sección sur de Ánimas Altas (Bachir Bacha y Llanos 2013: figs. 17, 22, 23; Bachir Bacha e.p.: fig. 5) no se encuentran tan alejadas, pues la distancia que las separa del Edificio de los Frisos no excede los 500 metros. 

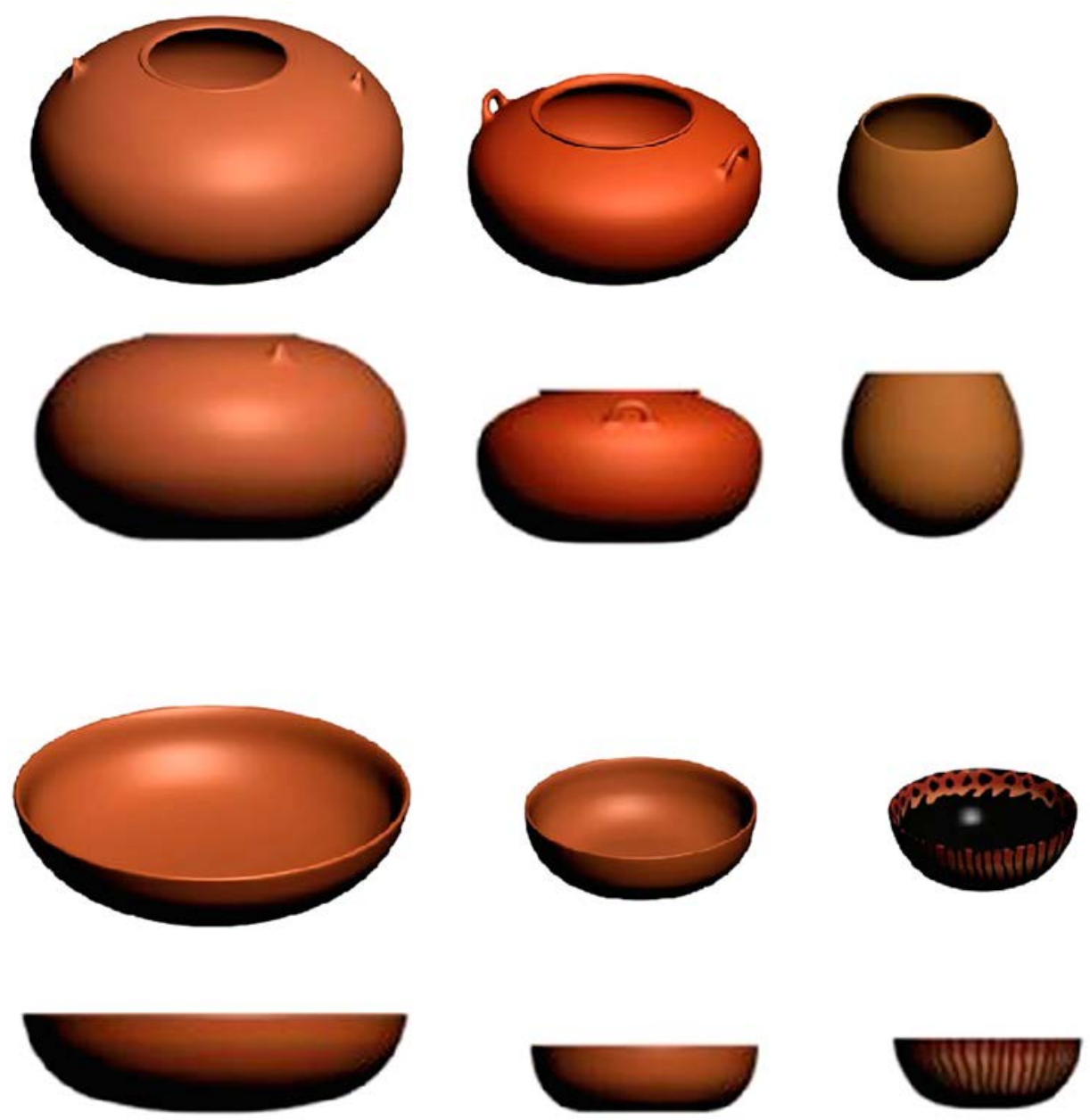

Figura 18. Reconstitución de vasijas paracas halladas en el Edificio de los Frisos (PAAA IP/Arqueosystems 2016).

La vida del Edificio de los Frisos no se limitó a su construcción y renovación, aunque estos momentos son los que dejaron más evidencias. En tiempos sagrados, los ambientes del Edificio de los Frisos (o algunos de ellos) estuvieron probablemente dedicados a ceremonias y rituales "comunales» y extra "comunales», en los que el culto a los ancestros parece haber estado omnipresente. Por otra parte, ciertos ambientes de este monumento también habrían podido servir de residencia para la élite y como almacenes de bienes, donde la élite tenía sus espacios para las actividades de vida diaria (dormir, comer, vestirse, producir, etc.). De hecho, la organización espacial del primer edificio apoya estos planteamientos. Los recintos, los depósitos laterales y el altar decorado con frisos en la parte posterior del edificio forman espacios restringidos y privados (Figs. 7a, 9, 10). El acceso acondicionado en el frontis sur limita la entrada hacia la plaza adyacente. Estos ambientes contrastan con los espacios abiertos de la zona norte del edificio: el atrio y la terraza, los cuales se prestan a manifestaciones públicas (Figs. 6, 7a, 8). Además las plazas vinculan al Edificio de los Frisos, una estructura central y las plataformas secundarias o anexas (Fig. 3a). Estas últimas estuvieron dedicadas a la producción de la parafernalia de culto y a la preparación de alimentos para ceremonias y agasajos. En su superficie, se observaron concentraciones de cerámica, restos malacológicos comestibles, así como vestigios de pequeños corrales. 

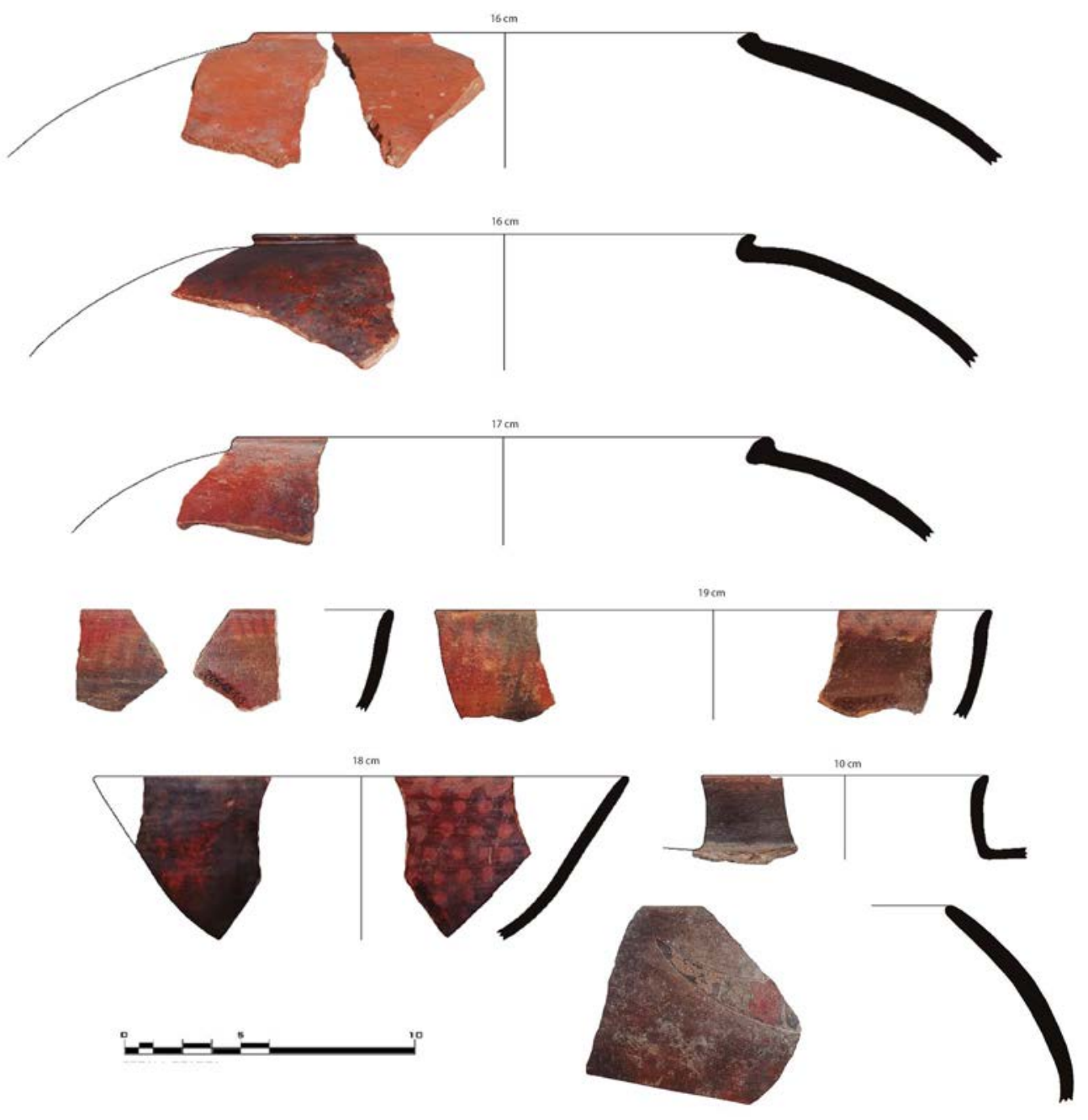

Figura 19. Cerámica ocucaje 9-10 registrada en los rellenos constructivos y de sello de las estructuras del Edificio de los Frisos (PAAA IP/Arqueosystems 2016).

Aunque en Ánimas Altas se pudo observar una concentración de edificios públicos al norte y otros de carácter doméstico y/o de producción al sur (ver supra descripción del sitio), en las estructuras de ambas zonas podemos distinguir espacios-tiempos rituales y otros de carácter doméstico, pero en diferentes escalas. En otras palabras, las estructuras domésticas y de producción registradas en Ánimas Altas contienen también espacios reservados a rituales; estos habrían sido privados, limitados a pequeńos grupos o «familias». En los espacios domésticos, se encontraron vestigios de altares y depósitos de ofrendas que apoyan esta idea. Estos espacios forman estructuras menos imponentes en comparación con los edificios públicos; son plataformas y terrazas bajas (50 centímetros), tienen recintos techados y se caracterizan por la simplicidad de los acabados de su arquitectura. Por otro lado, los espacios públicos por esencia político-religiosos disponían de lugares dedicados a "producciones rituales». Es el caso de la serie de pequeños corrales, espacio funcional durante el tiempo ritual y de carácter simbólico el resto del tiempo, por formar parte de la arquitectura monumental. ${ }^{9}$

La cultura material de Ánimas revela esta complejidad que se refleja en la dualidad a gran y pequeña escala, la imbricación, dicotomía y complementariedad. A su vez, esto constituye un 

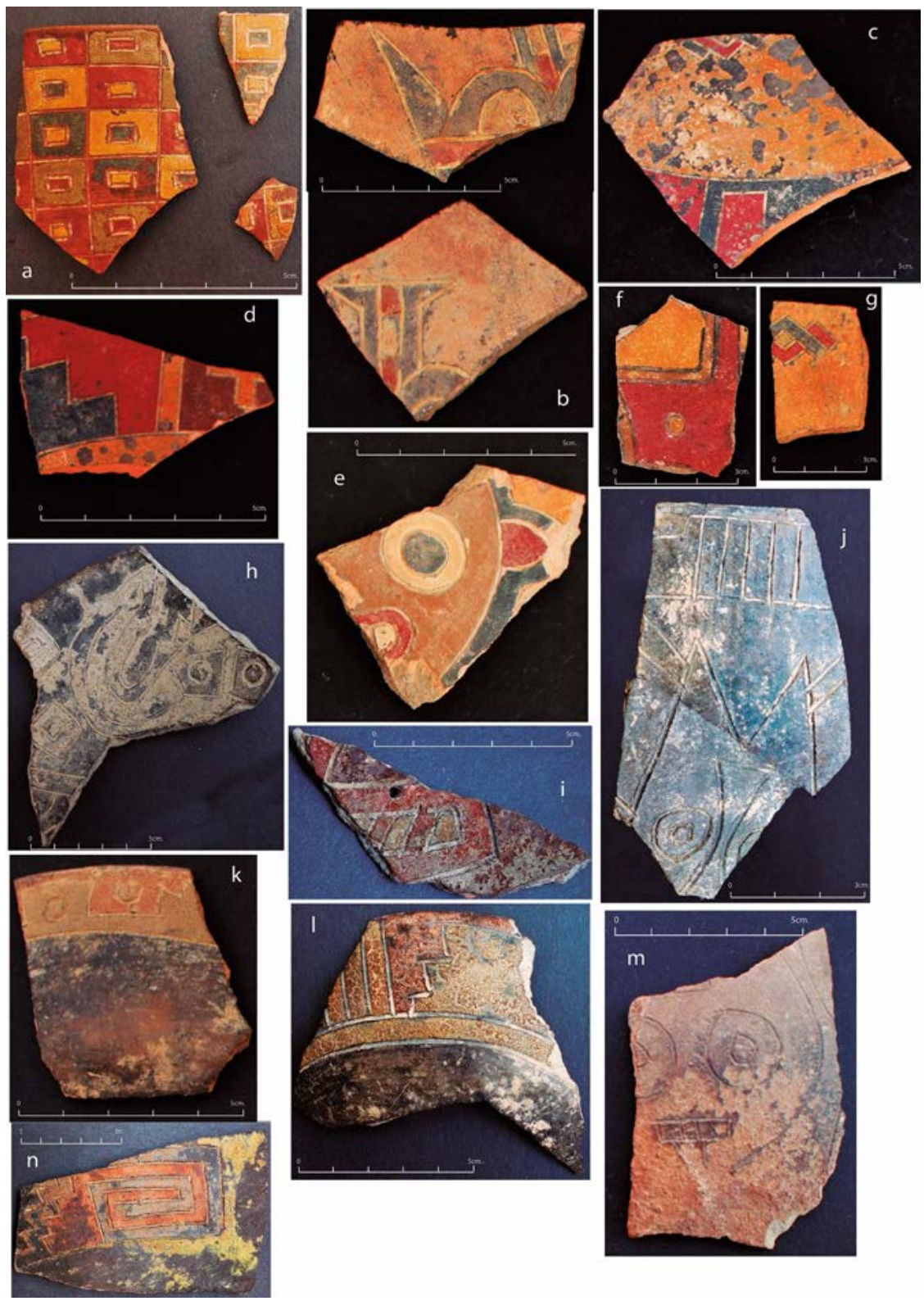

Figura 20. Cerámica ocucaje policroma e incisa, con pintura resinosa poscocción, registrada en los rellenos constructivos y de sello de las estructuras del Edificio de los Frisos (fotos: A. Bachir Bacha).

esquema alejado de los conceptos y dogmas de la clásica dicotomía entre lo ceremonial y lo doméstico. La cultura material del Edificio de los Frisos indica que los grandes establecimientos paracas están muy lejos de limitarse a centros exclusivamente ceremoniales. En realidad, en ellos, la política, religión y economía estuvieron fusionadas de manera inextricable, como lo enfatizan los datos arqueológicos en general y las ofrendas en particular. El material arqueológico del Edificio de los Frisos es el mismo que encontramos en otras estructuras de Ánimas: diversas materias primas, así como restos faunísticos y botánicos, restos de cadenas operativas de diversas manufacturas (cerámica, textil, lítico, figurinas, cuentas, óseo, etc.), materias importadas (obsidiana, Spondylus sp.). 


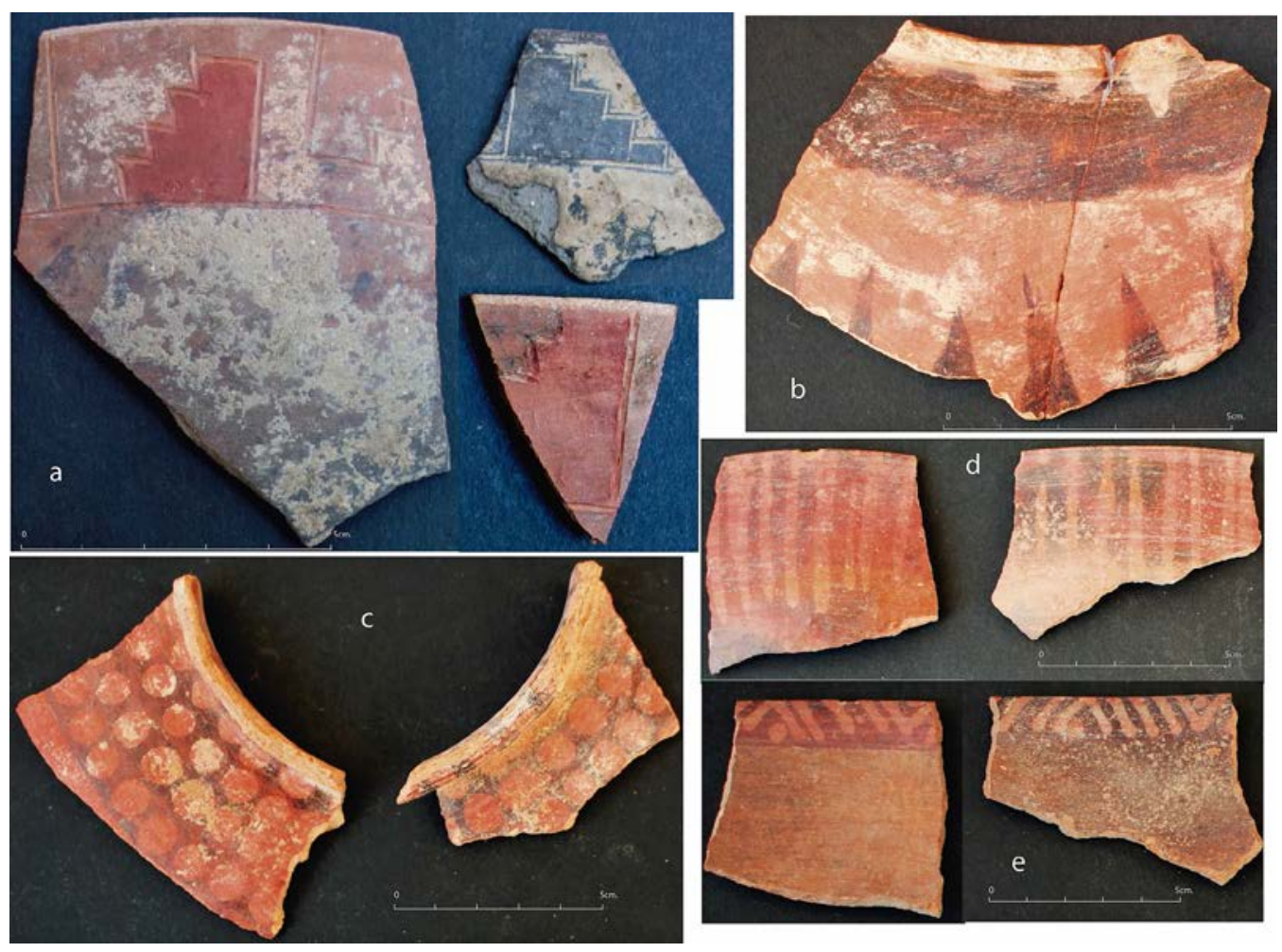

Figura 21. Cerámica ocucaje 9-10 decorada mediante la técnica del negativo y otra incisa con pintura poscocción, registradas en los rellenos constructivos y de sello de las estructuras del Edificio de los Frisos (fotos: A. Bachir Bacha).

Ellos evidencian un conjunto de actividades características de una antigua «ciudad» andina de la costa sur del Perú, cuyo territorio puede ser calificado como pluriocupacional. Su materialidad expresa un componente espacio-temporal e histórico que intentamos explicar en seguida.

\section{Una aproximación a las formaciones sociopolíticas paracas y sus dinámicas espacio-temporales}

Un rasgo característico de la arquitectura del Edificio de los Frisos y sus similares de Ánimas es el uso de bloques de arcilla sedimentaria (Figs. 11e, 11g), un material curiosamente documentado en construcciones muy antiguas de la costa norte del Perú. Es el caso, por ejemplo, de Ventarrón (Alva 2012), un sitio ubicado en el valle de Lambayeque que ha sido asignado al Período Precerámico. Más cerca del espacio y del tiempo de Ánimas, encontramos el mismo material constructivo en establecimientos satélites (Figs. 23h, 23i) ubicados en las cuencas de Callango y Ocucaje (Bachir Bacha 2014), y, en cierta medida, en Jauranga, aunque en este sitio los bloques de arcilla están asociados a adobes amorfos (Reindel e Isla 2013: 239).

El patrón arquitectónico del primer edificio (Etapa 1) con su plataforma de planta en «U» y su atrio dotado de una escalera central (Figs. 6, 7a, 8), nos remite a rasgos arquitectónicos norteños pues recuerda la tradición político-religiosa de los templos en «U» del Horizonte Temprano, a la cual se adscriben las entidades cupisnique, chavín y aquellas de la costa central de Lima. El patrón del recinto hundido (Etapa 2 del Edificio de los Frisos, Figs. 7b, 11f, 14) revela también rasgos arquitectónicos de aquella época. Si tomamos en cuenta los edificios paracas del valle de Chincha (Canziani 2013; Tantaleán et al. 2013), este patrón sigue vigente entre los paracas en su época tardía. 

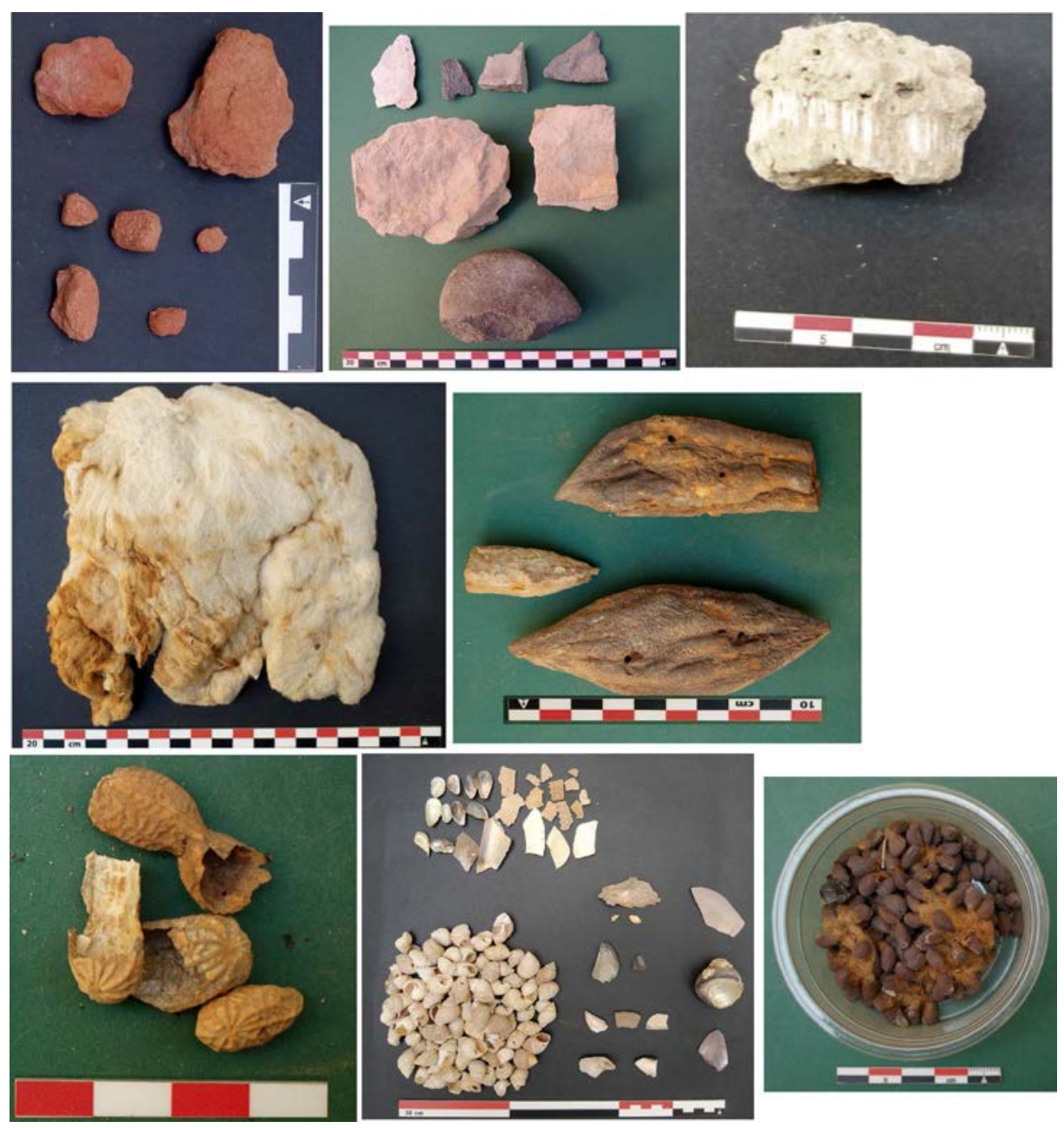

Figura 22. Materias primas, restos botánicos, faunisticos y malacológicos descubiertos en los rellenos del Edificio de los Frisos (fotos: A. Bachir Bacha).

Si bien la arquitectura del Edificio de los Frisos es de pequeña escala en comparación a los Templos en «U», ${ }^{10}$ cabe resaltar que su iconografía (atrio, altar) —asociada mayormente a cerámica de la fase Paracas tardío (Ocucaje 9-10) - comparte rasgos significativos con aquella de una época más temprana. Los frisos del atrio combinan íconos paracas y otros con rasgos norteńos cupisnique o chavín, al igual que la figura central del friso hallado en el Montículo $71 .{ }^{11}$ De hecho, en los muros laterales del atrio, destacan seres antropomorfos y zoomorfos, con fauces y colmillos felínicos, volutas y apéndices serpentiformes (Fig. 8, bloques de íconos 10 a 13). Estas imágenes son comunes en la iconografía cupisnique-chavín y en la arquitectura cívico-ceremonial de la costa central. Sin embargo, observamos que el cuerpo del felino grabado en el muro lateral este es el del Ser Oculado, una figura local y emblemática de los paracas. La representación del cuerpo del Ser Oculado de perfil, en forma de «ameba», es frecuente y característica de Paracas Tardío. También, se observa en los íconos plasmados en el muro central del atrio (Fig. 8, bloques 1, 4, 8, 9), y en las imágenes figuradas en cuencos de cerámica de Ánimas y de Ocucaje ${ }^{12}$ correspondientes a la época Paracas Tardío (Ocucaje 9-10). 

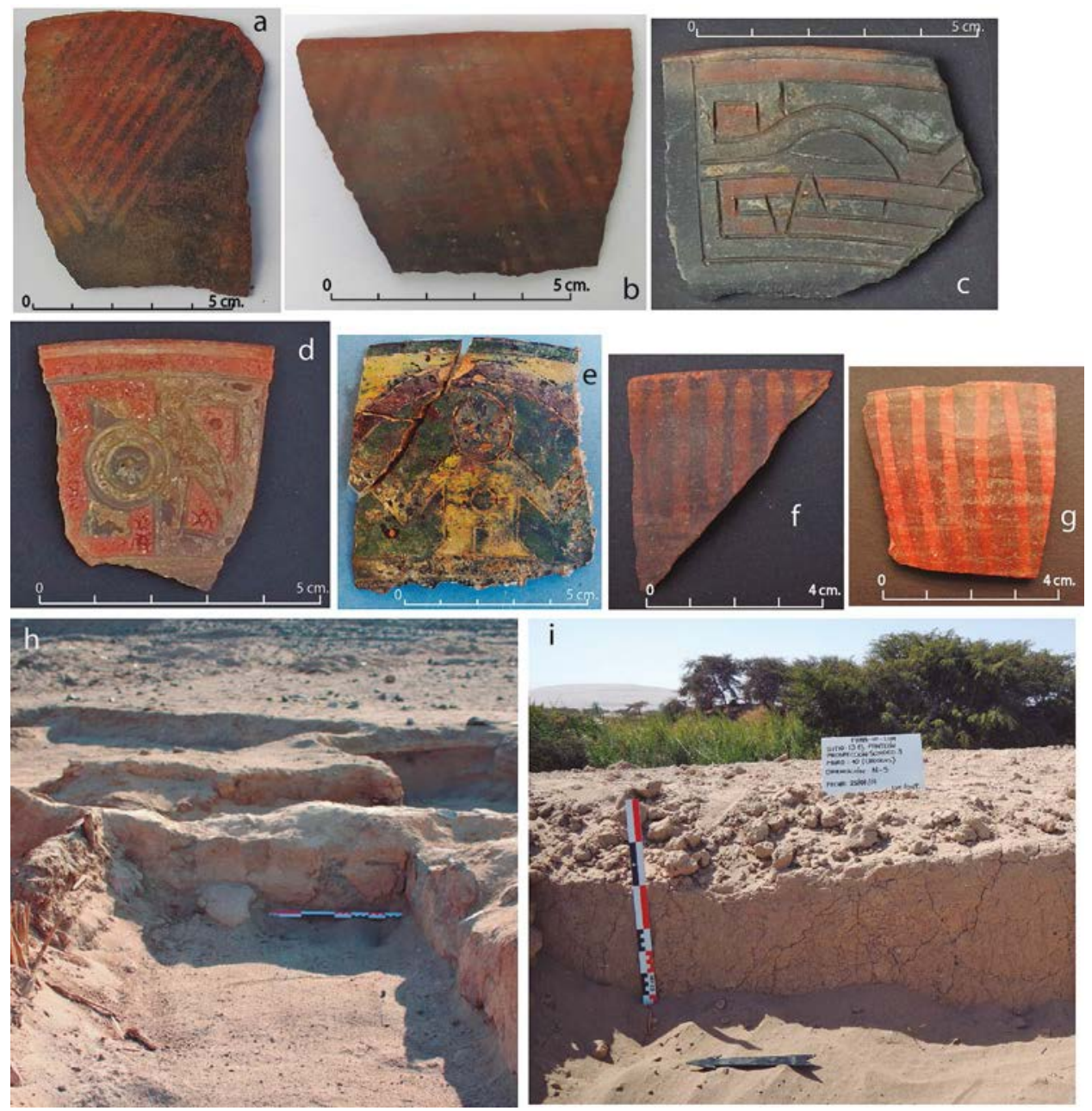

Figura 23. Arquitectura y cerámica halladas en las cuencas de Callango y Ocucaje (fotos: A. Bachir Bacha).

El friso grabado en el muro frontal presenta una asociación de íconos: felinos antropomorfos parecidos a motivos plasmados en la cerámica ocucaje 6-7-8, que combinan elementos paracas y otros cupisnique y chavín (Fig. 8, bloques de íconos 5, 7), otro ser híbrido (bloque 8), el Ser Oculado (bloque 9) que es una figura común en la cerámica de la fase Paracas Tardío (Ocucaje 9-10), un personaje de perfil con báculo (bloque 3) y otro con rostro radiante dotado de dardos (bloque 6). De la cabeza del Ser Oculado (bloque 9), brota una serpiente bicéfala con cabezas triangulares parecidas a aquellas grabadas en la cerámica y presentes en textiles de estilo Interlocking, elaborados con la técnica del brocado en Ánimas, ${ }^{13}$ pero también a otras grabadas en cerámica paracas tardío (Ocucaje 9) proveniente de otros sitios. ${ }^{14}$

El rostro dotado de dardos y volutas - que es conocido como el rostro radiante o motivo helíaco- grabado en el muro central del atrio (Fig. 8, bloque 6) aparece en general en soportes textiles y en monolitos y esculturas líticas. En Ánimas, se encuentra en un tejido doble tela de algodón hallada en D 1 (Área Doméstica 1). ${ }^{15}$ Otra variante con volutas más estilizada se encuentra en textiles paracas descubiertos en Cabezas Largas, Cerro del Gentil y Cahuachi. ${ }^{16}$ Asimismo, en un manto paracas doble tela en fibra de camélido (Momia 349) ${ }^{17}$ proveniente de Wari Kayán, el rostro radiante igualmente estilizado surge de la cabeza de un felino designado como el Ser Oculado. 
Hay que destacar la presencia recurrente de este símbolo en estelas ${ }^{18}$ halladas en la región del Titicaca y pertenecientes a la tradición político-religiosa de Yaya-Mama que se desarrolla según Stanish (2001: 202) alrededor de 500 a 200 a.C.

La iconografía del friso grabado en el muro del altar ilustra motivos geométricos que combinan formas hexagonales y piramidales articulados de manera tal que crean un juego de reflejo y correspondencias. Se trata de una cadena de rombos en los que se insertan pirámides concéntricas de cuatro gradas, opuestas por las bases. El cruce de las líneas de los rombos crea triángulos en los que se inscriben también pirámides concéntricas opuestas esta vez por sus cimas. Las figuras creadas por las pirámides concéntricas recuerdan a la cruz andina o chakana (Fig. 9), un símbolo que transciende el tiempo y el espacio paracas (Bachir Bacha 2015). Otro friso hallado en Ánimas en el Montículo 71 presenta un motivo semejante e ilustra un segmento de la cadena de los rombos, una «X» en la que igualmente se inscriben pirámides concéntricas opuestas por sus cimas. Al lado de esta imagen, se grabó una pequeña cruz (Bachir Bacha y Llanos 2013: fig. 21).

En el estado actual de nuestros conocimientos, no tenemos referencias de motivos semejantes que combinen rombos y pirámides en otros soportes, tanto en Ánimas como en otros sitios paracas. Sin embargo, la representación del encadenado de rombos se registró en soportes textiles y alfareros en dos contextos excavados en Ánimas (Montículos 26 y 71). ${ }^{19}$ Asimismo, se encuentra grabado en la cerámica paracas, y tejido o bordado en los textiles procedentes de Ocucaje y las necrópolis de la Península de Paracas. ${ }^{20}$ De forma romboidal u ondulante, este motivo parece tener sus raíces en la iconografía cupisnique y fue plasmado en objetos de metal y de cerámica.

En la arquitectura del Precerámico, el símbolo de la chakana se reporta en Ventarrón en una estructura de planta escalonada (Alva 2012: fig. 90). Representaciones más parecidas al símbolo que evoca la chakana del friso del altar se han registrado en el Templo de Kalasasaya y el Kheri Kala (Berenguer 2000: 19) del complejo de Tiahuanaco, cuyos inicios, según Stanish, se remontan a los inicios de nuestra era (2001: 192), así como en el friso del Palacio Maranga en Lima asignado al Intermedio Tardío. ${ }^{21}$ La cruz cuadrada, otra variante de la chakana, representa los ojos y adorna el cuerpo del felino figurado en el tejido triple tela hallado en contexto de una tumba de élite excavada en el Montículo 71 (Bachir Bacha y Llanos 2013: fig. 27a). Asimismo, este símbolo asociado en general a felinos se encuentra también representado como una simple cruz cuadrada o dotada de escalones en los objetos y en las estelas de Chavín de Huantar. ${ }^{22}$

Por su técnica e iconografía, los textiles descubiertos en el Edificio de los Frisos presentan similitudes con aquellos descubiertos en una tumba excavada en Montículo 71 y en el Edificio de las Banquetas (Montículo 26) en Ánimas Altas. ${ }^{23}$ La representación del felino con una boca en «V» plasmada en el textil hallado en el Corral 4 (Fig. 17) recuerda a figuras del Ser Oculado pintadas en telas provenientes de Ocucaje y de Cabezas Largas. La misma cara aparece en los textiles reportados en Wari Kayán, en telas registradas en el valle de Pisco o en textiles exhumados en contextos funerarios de Cahuachi. ${ }^{24}$

El material cerámico recuperado en los rellenos constructivos y de sello corresponde en términos de tipología mayormente a Ocucaje 9-10 y muy poco a Ocucaje 8 (dos fragmentos). Un fragmento de Ocucaje 8 (Fig. 20a) ilustra motivos cuadrados concéntricos parecidos a los grabados en los frisos del atrio (Fig. 8, bloque 13).

La cerámica incisa con o sin pintura poscocción de tipo ocucaje 9 se caracteriza por la variedad de diseños. Presenta similitudes significativas con la de sitios Paracas de la cuenca de Callango (Bachir Bacha 2013, 2014; Figs. 23a, 23b, 23c) y con especímenes documentados en varios sitios de la costa sur: Cerro Córdova en la cuenca de Ocucaje (Figs. 23d, 23e), Cerro Colorado en la Península de Paracas, Tambo Colorado en el valle de Pisco, Cerro del Gentil en el valle de Chincha, Jauranga en el valle de Palpa y Cahuachi en la cuenca de río Grande de Nasca. ${ }^{25}$ Cabe notar que alfares designados como ocucaje 10 se registraron en los mismos estratos que los anteriormente señalados. Entre los fragmentos, destaca la imagen de un personaje designado como el Ser Oculado, con la cabeza partida y ojos concéntricos (Fig. 20j), idéntico a personajes plasmados en piezas recuperadas en Cerro Córdova y Cerro Blanco en la cuenca de Ocucaje. ${ }^{26}$ 
$\mathrm{Al}$ igual que otros sectores excavados, la cerámica con decoración negativa catalogada como de tipo ocucaje 9-10 (en particular los cuencos) tiene el mayor porcentaje. Si bien este tipo de alfar es el más abundante en Ánimas Altas, pocos datos indican su presencia en otros valles. Actualmente, sabemos que algunos especímenes proceden de Cerro Córdova (Figs. 23f, 23g), de Cerro Colorado (Tello 1959: lámina VIII A), del valle alto de Ica (Massey 1992: figs. 5, 6) y Palpa (Isla et al. 2003: fig. 29g), a diferencia de la cerámica con decoración policroma poscocción, cuyo radio de distribución es más extenso. Este dato sugeriría la producción de cerámica con decoración negativa en la cuenca de Callango, mientras que la polícroma incisa poscocción y la incisa monócroma se confeccionaron en varios lugares.

Asimismo, cerámica de influencia paracas ha sido reportada en el sitio Los Patos en el valle de Cañete (Wallace 1963: figs. 1 a, b, c); por su parte, en el sitio León Dormido, en el valle de Mala, se registró un conjunto de tumbas, una de las cuales incluía en su ajuar una botella paracas de la fase Ocucaje 5 (Balbuena 2013: 71).

En cuanto a otros materiales, se ha identificado en el valle de Palpa y en la cuenca del río Grande de Nasca algunos textiles, petroglifos y geoglifos (Reindel e Isla 2006: fig. 5; Llanos 2009: figs. 5.15c, 5.34). Un dato importante es el descubrimiento en el marco del PAAA IP de un geoglifo que abarca dos kilómetros, trazado en la Pampa Alto Avería (Ullujaya), una zona de transición entre Callango y la cuenca del río Grande de Nasca. Es muy posible que este geoglifo se remonte a la época de Paracas. Orientado en sentido este-oeste, converge de un lado hacia sitios Paracas de Callango y de otro hacia Palpa, que conecta de cierta manera las dos zonas. Hoy en día, los lugareños conciben este geoglifo como un camino y relatan seguirlo para llegar a Palpa (Bachir Bacha 2014).

La cerámica paracas o de imitación paracas registrada fuera de los valles de Ica, Chincha, Pisco, Palpa y Nasca corresponde mayormente a los subestilos Ocucaje 8, 9 y 10. Algunos datos arqueológicos postulan su presencia en áreas de la sierra, como Ayacucho, Huancavelica y Huancayo (Lumbreras 1974: 80; Ruiz 1977: 35; Kaulicke 2013: 298). En la costa central, cerámica con rasgos paracas ha sido reportada en Ancón y en el valle de Rímac (Tabio 1965: 79; Silva et al. 1982: 63- 64; Palacios 1987-1988: 16, 20), y al sur de Nasca en el valle de Acarí (Riddel y Valdez 1987-1988: 8).

Las evidencias de interacciones entre la costa sur y la costa central no se limitan a textiles y alfares. Las figurinas descubiertas en el Edificio de los Frisos presentan características faciales y técnicas de elaboración similares a aquellas reportadas en Huachipa, Huallamarca y Puruchuco en el valle del Rímac, y asignadas a fines del Horizonte Temprano e inicios del Horizonte Temprano (Morgan 1996: Plate 3).

\section{Comentarios finales}

Si la variación «estilística» observada en la iconografía de los frisos hallados en los Montículos 1 y 71 no se inscribe en diacronía ${ }^{27}$ —en el sentido que los motivos de los frisos no han sido grabados en diferentes épocas o «fases»—, tendría entonces otra explicación. Creemos que la iconografía de los frisos manifiesta un discurso histórico y territorial. Relataría tanto el presente de los paracas a través de íconos locales (Ser Oculado), como las épocas remotas a través de íconos norteños (felinos con rasgos cupisnique y chavín). Estos últimos grabados en la arquitectura paracas tardío reenvían a los orígenes, o bien a una herencia cultural norteńa enraizada en el territorio y en la memoria de la población paracas. El abanico, el cuchillo y la posición volante del felino grabado en el friso del Montículo 71, elementos comunes a los paracas y nascas (cerámica de Nasca 1, textiles nasca catalogados de Paracas Necrópolis), representarían el territorio local y sus estrechos vínculos con las poblaciones vecinas que dependían de Ánimas en cierto grado y en un momento dado. El rostro radiante reenvía a un territorio exógeno. Este fue plasmado en los textiles paracas hallados en Ánimas, en los de la Península y en Cahuachi, y sería una de las evidencias que indicaría la conexión del territorio paracas a través de su periferia con regiones lejanas como el Altiplano. 
La noción de espacio-tiempo estaría también representada en el friso del Altar (Fig. 9). El glifo de la pirámide expresaría la noción del poder y la territorialidad, mientras que el encadenado remitiría a la noción del tiempo. ${ }^{28}$ La combinación de ambos representaría el espacio-tiempo sagrado, administrado y controlado por los ancestros, cuyas tumbas colocadas en los edificios principales son ilustradas por pirámides invertidas. Ellas están relacionadas con el mundo nocturno de los muertos, mientras que las otras (pirámides verticales) representan el mundo diurno, de los vivos. La arista del rombo figuraría la noción de la ruptura y del cambio, en otras palabras, el fin de un ciclo y el inicio de otro. Los datos arqueológicos confirman esta idea, pues el análisis arquitectónico demuestra bien el enterramiento de un edificio y la construcción de otro.

Dado que esta iconografía se refiere a la memoria y a los mitos que pueden aludir a hechos históricos, funciona también como un sistema de comunicación. Sus elementos estructurales (desarrollo de los íconos en paneles, bloques de íconos y glifos insertados en cuadros, simetría, inversión, ruptura, etc.) y su codificación (imágenes que combinan íconos y glifos) le otorgan el estatus de una escritura ideográfica. ${ }^{29}$ El uso consciente de íconos del presente en contraste con aquellos del pasado, aunque aluden a tiempos ancestrales y míticos, no se encuentra exento de una connotación histórica.

Al igual que otras estructuras excavadas en Ánimas, los vestigios arqueológicos del Edificio de los Frisos apuntan hacia una ocupación de su territorio por varios grupos cuya identidad se debería a su especialización productiva o política, su lugar de procedencia (ayllus, mitades cosmogónicas, cuencas, otros valles etc.) y — quizás - su origen etnolingüístico. Sin embargo, estos grupos formaron entidades sociopolíticas paracas en el valle bajo de Ica (Bachir Bacha y Llanos 2013; Bachir Bacha e.p.) y ocuparon un territorio definido, en el que explotaron sus recursos y estuvieron involucrados en las actividades rituales del centro. En este caso, parece difícil pensar que lo que cimentaba la organización social eran lazos de parentesco. Creemos, más bien, que las relaciones político-religiosas fundamentaban estas entidades. El aspecto religioso se refiere a los ritos y las ceremonias en los cuales se rendía culto a los ancestros, que de cierta manera están presentes y cooperan a través de los protagonistas de los ritos. Lo religioso tiene siempre una dimensión política, porque los ritos legitiman el poder y el orden en el seno de la sociedad gobernada por la élite.

El componente norteño (cupisnique, chavín, costa central) está muy presente, como lo indica la arquitectura (frisos, patrón de planta en «U», recinto hundido). ¿Los ancestros fundadores de Ánimas habrían tenido origen norteño? ¿Serán sus herederos quienes detentaban la gestión política y religiosa de Ánimas? Por su parte, el componente serrano no parece limitarse a la sierra adyacente, como lo atestigua la cara radiante. El rasgo guerrero de este motivo plasmado en la arquitectura indicaría algo más que intercambios de bienes. ¿¿Sería la representación de la alteridad, del foráneo lejano, o bien la representación de Nasca, el territorio periférico vecino, a través del cual llegó este símbolo? No hay que perder de vista que la periferia que reemplazará a Callango después el abandono de Ánimas es Nasca y su centro político-religioso Cahuachi.

En lo que se refiere al territorio paracas, aunque los datos arqueológicos disponibles son limitados por no contar con más detalles sobre otras manifestaciones culturales distintas a la cerámica y los textiles, podemos postular que en la época Paracas Tardío existía probablemente un territorio principal, que incluía dos zonas nucleares: el valle de Ica, y los valles de Chincha y Pisco. ${ }^{30} \mathrm{~A}$ estas áreas nucleares se vinculan dos periferias: al noroeste Topará-Cañete y al sureste Palpa-Nasca. Estas periferias interconectan las áreas nucleares con la costa central, la sierra adyacente y con los valles ubicados al sur de Nasca, más lejanos. A través de estos territorios, circulaban en un eje noroestesureste y en otro este-oeste materias, productos y bienes de prestigio. Los conceptos y símbolos paracas probablemente circulaban y se transmitían a través de grupos especializados que ocupaban los centros y también las periferias. De ser así, estos grupos ocupaban un lugar destacado en la jerarquía social. Un ejemplo representativo es la cantidad y variedad de cerámica paracas hallada en tumbas en la región de Palpa, donde se registraron sitios de tipo caserío o grandes aglomeraciones (Reindel e Isla 2006). La presencia de cerámica típicamente paracas, arquitectura parecida a la de Ánimas y el geoglifo registrado en la Pampa Alto Avería (Bachir Bacha 2014) consolidan la idea de que Palpa pertenecía política y religiosamente a la esfera de Ánimas. Es muy sorprendente que 
una periferia de tal importancia no se convirtiese en área nuclear con un centro de la envergadura de Ánimas o Cahuachi. Este cuestionamiento nos lleva a pensar que los factores ambientales no siempre son elementos decisivos para el surgimiento de grandes centros. Parafraseando a Godelier (2010), es la historia singular de un lugar y de un grupo lo que explica sus transformaciones.

La cerámica paracas tardío registrada fuera de las áreas nucleares y sus periferias revela una dinámica de intercambios a larga distancia, mantenida por los paracas con otras poblaciones, como lo han señalado varios autores (Llanos 2009, Bachir Bacha y Llanos 2013; Kaulicke 2013). $\mathrm{Su}$ presencia en otras regiones, como objetos originales o como imitaciones, comprueba sobre todo la circulación de la simbología paracas a escala extra regional. Esta especie de difusión cultural a larga distancia refleja el prestigio político-religioso logrado por los grandes establecimientos instalados en los valles costeños.

Sin embargo, parece difícil postular una ocupación paracas stricto sensu en los territorios alejados de las zonas nucleares y sus periferias tomando en cuenta la presencia de cerámica paracas que, además, aparece en cantidades escasas. En esas zonas, los datos arqueológicos reportan la presencia de otros estilos de cerámica y otro tipo de arquitectura. Por ejemplo, en la sierra, las construcciones adoptan una planta circular (véase en Reindel e Isla, este número; Mendoza, este número), y, en la costa central, predominan otros materiales y otro tipo de construcciones.

A partir de estos datos, podemos postular que el territorio de la cultura Paracas, orientado paralelamente al océano Pacífico y a la sierra, se ordena en una banda longitudinal de 400 kilómetros de extensión de norte a sur y de 50 a 100 kilómetros de este a oeste. Se trata de un gran segmento estructurado por dos zonas nucleares y dos extremos periféricos simétricos. Estas áreas separadas por pampas, ríos y pequeńas estribaciones ocupan el litoral y los valles, y abarcarían la yunga marítima. Las pampas y llanuras desérticas — aparentemente vacías - están marcadas por geoglifos, paravientos y abrigos, vestigios que evidencian la continuidad del territorio y la articulación de sus componentes. En este sentido, el territorio no parece tan organizado por su naturaleza geográfica; más bien, es producto de una construcción cultural.

Frente a una suerte de fragmentación política, las evidencias arqueológicas tienden hacia una unidad cultural a lo largo de este territorio, detectable en la iconografía y en una variedad de estilos de cerámica y textiles compartidos por la mayoría de sitios Paracas. Esto nos lleva a pensar que el aspecto segmentario del territorio paracas — que a primera vista parece vinculado a un menor grado de cohesión social y política, como a menudo son calificadas las antiguas sociedades prehispanicastendría más bien su origen en una lógica simbólica, una manera de organizar el espacio y la sociedad. Este es otro aspecto de la cultura Paracas y sus organizaciones político-sociales que queda por indagar.

\section{Agradecimientos}

La autora agradece al Ministerio de los Asuntos Exteriores de Francia, que auspicia el programa; al Ministerio de Cultura del Perú, por otorgar los permisos para la realización de las investigaciones, así como la Dirección del Desarrollo de la Investigación de la EHESS, la Dirección Desconcentrada de Cultura de Ica, por sus continuos apoyos. Se agradece a la población del Solar por su hospitalidad y ayuda en la instalación del campamento. Asimismo, se agradece a los arqueólogos y alumnos que participaron en las excavaciones y en los análisis de ciertos materiales, en especial, a Oscar Daniel Llanos Jacinto, Marco Taquiri, Lizbeth Pari, Melly Muñoz, Erik Maquera y Stephany Rodríguez.

\section{Notas}

${ }^{1}$ Las investigaciones del PAAA IP son regularmente auspiciadas por el Ministerio de Asuntos Exteriores de Francia y la Escuela de Altos Estudios en Ciencias Sociales, y son autorizadas por el Ministerio de Cultura de Perú.

${ }^{2}$ El piso de este recinto guarda casi la misma altura de los pisos de los ambientes identificados al sur del edificio. 
${ }^{3}$ El grosor estimado de los muros es de 35 a 40 centímetros; el muro central mide 14,6 metros de largo; el este, 6,6 metros; y el oeste, siete metros.

${ }^{4}$ Ochenta por 80 centímetros, altura 20 a 25 centímetros y aproximadamente 15 centímetros de grosor.

${ }^{5}$ Largo tres metros, altura un metro, grosor 30 centímetros.

${ }^{6}$ Mide cinco metros de largo, dos metros de alto.

${ }^{7}$ El análisis fue realizado por Llanos y Bachir Bacha (cerámica de las temporadas 2014-2016) y por Erik Maquera y Stephany Rodríguez (cerámica de la temporada 2015).

${ }^{8}$ Estos, generalmente, se consideran objetos procedentes de la sierra.

${ }^{9}$ Los pequeños corrales registrados en las estructuras domésticas y/o de producción (sector 13) están contiguos a recintos techados y son solo dos, lo que permite pensar que sean más funcionales en tiempos ordinarios.

${ }^{10}$ Como Huaca de los Reyes, Garagay, Mina Perdida y Chavín de Huantar.

${ }^{11}$ Bachir Bacha y Llanos 2011: fig. 5; Bachir Bacha y Llanos 2013: fig. 21.

${ }^{12}$ Ver entre otros Figs. 56, 59 a, c en Menzel et al.1964; Fig. 84 en Sawyer 1966.

${ }^{13}$ Ver Fig. 27 c en Bachir Bacha y Llanos 2013; Fig. 7en Bachir Bacha y Llanos 2011.

${ }^{14}$ Ver Fig. 53 a, b, c en Menzel et al. 1964.

${ }^{15}$ Ver Fig. 27 i en Bachir Bacha y Llanos 2013.

${ }^{16}$ Ver respectivamente las figuras publicadas en Engel 1991: Fig.70; Tantaleán et al. 2013: Fig.15; Llanos 2009: Fig. 5.15c.

${ }^{17}$ Textil conservado en el MNAAH, Lima.

${ }^{18}$ Ver Fig. 5.15a en Llanos 2009.

${ }^{19}$ Ver Fig. 3 a, b en Bachir Bacha y Llanos 2011.

${ }^{20}$ Ver Lam. 11a, Fig. 39b en Menzel et al. 1964; Fig. 2 en Wallace 1960; Fig. 4b en Wallace 1962; Fig. 11 en Frame 1994.

${ }^{21}$ Ver la foto de este friso en Fuentes fotográficas de Lima antigua.

22 Ver Fig. 262 en Campana 1995; Figs. 141,145, 161, 188 en Burger 1992.

${ }^{23}$ Ver Fig. 27a en Bachir Bacha y Llanos 2013.

${ }^{24}$ Ver respectivamente Fig. 5 en King 1983; textil de la Momia 349 (MNAAH, Lima); Fig. 118 en Sawyer 1966; Fig. 71 en Engel 1991; Fig. 11. 2b en Llanos 2009.

${ }^{25}$ Ver respectivamente láminas V, VIII, X en Tello 1959; Figs. 9, 10, 12 en Engel 1957; figuras de la cerámica presentada por Tantaleán et al. en este número; Figs. 22, 26 y 29 en Isla et al. 2003; Fig. 5.33a en Llanos 2009; Fig. 8a en Orefici 2012.

${ }^{26}$ Ver Fig. 126 en Sawyer 1966; Fig. 60 b y e en Menzel et al. 1964.

${ }^{27}$ Recordamos que los frisos se encuentran en los mismos contextos que la cerámica y los textiles paracas tardío, esencialmente ocucaje 9-10; estos mismos presentan una variación tecnológica y de «subestilos».

${ }^{28}$ Para un análisis detallado de estos símbolos, se puede consultar Bachir Bacha y Llanos (2011: 223).

${ }^{29}$ Este tema será detallado en una publicación en curso (Bachir Bacha e.p.).

${ }^{30}$ Para más detalles sobre los sitios registrados en el valle de Chincha, se puede remitir a los trabajos de Canziani (2013) y Tantaleán et al. (2013). 


\section{REFERENCIAS}

Alva Meneses, I.

2012 Ventarrón y Collud. Origen y auge de la civilización en la costa norte del Perú, Proyecto Especial Naylamp Lambayeque, Ministerio de Cultura del Perú.

Bachir Bacha, A.

2007 Dinámica y desarrollo de un centro ceremonial andino. El caso de Cahuachi, Arqueología y Sociedad 18, 69-94.

2013 Programme archéologique Ánimas Altas, Ica Pérou, Rapport sur la campagne 2013, présenté à la commission consultative des recherches archéologiques à l'étranger, MAEDI, Paris.

2014 Programme archéologique Ánimas Altas, Ica Pérou, rapport sur la campagne 2014, présenté à la commission consultative des recherches archéologiques à l'étranger, MAEDI, Paris.

2015 Programme archéologique Ánimas Altas, Ica Pérou, rapport sur la campagne 2015, présenté à la commission consultative des recherches archéologiques à l'étranger, MAEDI, Paris.

2016 La arquitectura Paracas en Ánimas Altas/Ánimas Bajas, valle de Ica: técnicas y semántica, Actas del I Congreso Nacional de Arqueología, 247-257, Ministerio de la Cultura del Perú, Lima.

e.p. $\quad$ Paracas Geography and Culture, Encyclopedia of Global Archaeology, Springer.

Bachir Bacha, A. y O.D. Llanos J.

2011 Arqueología e iconografía de los textiles paracas descubiertos en Ánimas Altas, Ica, Perú, en: V. Solanilla (ed.), Actas de las V Jornadas Internacionales sobre Textiles Precolombinos, 211-230, Universidad Autónoma de Barcelona, Publicaciones del Grup d'Estudis Precolombins 6, Barcelona.

2013 ¿Hacia un urbanismo paracas en Ánimas Altas/Ánimas Bajas (valle de Ica)?, en: A. Bachir Bacha y J. Dulanto (eds.), Paracas: nuevas evidencias, nuevas perspectivas, Boletín de Arqueología PUCP 17, 169-204.

Balbuena, L.

2013 Evidencias paracas en los valles de Pisco y Mala, en: A. Bachir Bacha y J. Dulanto (eds.), Paracas: nuevas evidencias, nuevas perspectivas, Boletin de Arqueología PUCP 17, 57-75.

\section{Berenguer, J.}

2000 Tiwanaku. Señores del lago sagrado, Museo Chileno de Arte Precolombino, Santiago.

\section{Burger, R.}

1992 Chavin and the origin of Andean civilization, Thames \& Hudson, Londres.

\section{Campana, C.}

1995 Arte chavin. Análisis estructural de formas e imágenes, Universidad Nacional Federico Villarreal, Lima.

Canziani, J.

2013 Arquitectura, urbanismo y transformaciones territoriales del Periodo Paracas en el Valle de Chincha, en: A. Bachir Bacha y J. Dulanto (eds.), Paracas: nuevas evidencias, nuevas perspectivas, Boletín de Arqueología PUCP 17, 9-29.

Cook, A.

1994 Informe final de las investigaciones de reconocimiento en la parte baja del valle de Ica, 1988-1990, Instituto Nacional de Cultura, Lima.

\section{Engel, $\mathbf{F}$.}

1957 Early Sites in the Pisco Valley of Peru: Tambo Colorado, American Antiquity 23, 34-45. https://doi. org/10.2307/277278

1991 Un desierto en tiempos prehispánicos. Río Pisco, Paracas, Rio Ica, Centro de Investigación de Zonas Áridas, Universidad Nacional Agraria La Molina, Lima.

\section{Frame, $M$.}

1994 Las imágenes visuales de estructuras textiles en el arte antiguo del Perú, Revista Andina 12 (2), 295-372, Cuzco.

Godelier, $\mathrm{M}$.

2010 Les tribus dans l'Histoire et face aux États, Éditions CNRS, Paris.

Isla, J. , M. Reindel y J. C. de La Torre

2003 Jauranga: Un sitio Paracas en el valle de Palpa, costa sur del Perú, Beiträge zur Allgemeinen und Vergleichenden Archäologie 23, 227-274, Mainz. 
Kaulicke, P.

2013 Avances recientes en perspectiva. Algunos comentarios finales, en: A. Bachir Bacha y J. Dulanto Brescia (eds.), Paracas: nuevas evidencias, nuevas perspectivas, Boletín de Arqueología PUCP 17, 291-300.

King, $M$.

1983 The Painted Mummy Bundles of Ocucaje (Peru), Indiana 8, 243-266, Berlín.

Lumbreras, L.

1974 Las fundaciones de Huamanga. Hacia una prehistoria de Ayacucho, Editorial Nueva Educación, Lima.

Llanos, O. D.

2009 Le bassin du Rio Grande de Nazca, Pérou: Archéologie d’un État andin 200 av. J.-C.-650 ap. J.-C., British Archaeological Reports International Series, Oxford.

Massey, $S$.

1983 Antiguo Centro Paracas, Ánimas Altas, en: J. A. de Lavalle (ed.), Culturas precolombinas: Paracas, Colección Arte y Tesoros del Perú, 134-160, Banco de Crédito del Perú, Lima.

1990 Paracas, Inca-Perú 3000 d'histoire, tomo I, 144-155, Musées royaux d'Art et d'Histoire, Bruxelles.

1992 Investigaciones arqueológicas en el valle alto de Ica: Periodo Intermedio Temprano 1 y 2, en: D. Bonavia (ed.), Estudios de Arqueología Peruana, 215-236, Fomciencias, Lima.

Menzel, D., J.H. Rowe y L. Dawson

1964 The Paracas Pottery of Ica. A Study in Style and Time, American Archaeology and Ethnology 50, University of California Publications, Berkeley.

Morgan, A.

1996 The pre-Colombian pottery figurines of the Central Coast of Peru, tesis doctoral, Institute of Archaeology, University College London.

Oficina Nacional de Evaluación de los Recursos Naturales (ONERN)

1971 Inventario, evaluación y uso racional de los recursos naturales de la costa: Cuenca del rio Ica, ONERN, Lima.

Orefici, G.

2012 Cahuachi capital teocrática Nasca, Universidad San Martín de Porres, Lima.

Palacios, J.

1987- La secuencia de la cerámica temprana del valle de Lima en Huachipa, Gaceta Arqueológica Andina

1988 16, 13-24.

Reindel, M. y J. Isla

2006 Evidencias de culturas tempranas en los valles de Palpa, costa sur del Perú, en: P. Kaulicke y T. D. Dillehay (eds.), Procesos y expresiones de poder, identidad y orden tempranos en Sudamérica, Boletín de Arqueología PUCP 10, 237-283.

2013 Jauranga: Una aproximación a la ocupación paracas en los valles de Palpa, en: A. Bachir Bacha y J. Dulanto (eds.), Paracas: nuevas evidencias, nuevas perspectivas, Boletín de Arqueología PUCP 17, 231-262.

Riddel F. y L. Valdez

1987- Hacha y la ocupación temprana del valle de Acarí, Gaceta Arqueológica Andina 16, 6-10.

1988

Ruiz, E.

1977 Arqueología de la ciudad de Huancavelica, Artes Gráficas S.A, Lima.

\section{Sawyer, A.}

1966 Ancient Peruvian ceramics. The Nathan Cummings collection, The Metropolitan Museum of Art, Zurich.

Silva J., K. Hirth, R. García y J. Pinilla

1982 El valle del Rímac hace 2500 años: Huachipa-Jicamarca, Boletín de Lima 21, 59-68.

Stanish, C.

2001 Formación estatal temprana en la cuenca del lago Titicaca, Andes Surcentrales, en P. Kaulicke y W. Isbell (eds.), Huari y Tiwanaku: modelos versus evidencias, Boletín de Arqueología PUCP 5, 189-215. 
Tabio, E.

1965 Excavaciones en la costa central del Perú, 1955-958, Academia de Ciencias, Departamento de Antropología, La Habana.

Tantaleán, H., C. Stanish, M. Zegarra y B. Nigral

2013 Paracas en el valle de Chincha: nuevos datos y explicaciones, en: A. Bachir Bacha y J. Dulanto Brescia (eds.), Paracas: Nuevas evidencias, nuevas perspectivas, Boletín de Arqueología PUCP 17, 31-56.

Tello, J. C.

1959 Paracas. Primera parte, The Institute for Andean Research New York, Empresa Gráfica T. Scheuch S.A., Lima.

Unkel, I.

2006 AMS-14C-Analysen zur Rekonstruktion der Landschafts-und Kulturgeschichte in der Region Palpa (S-Peru), Inaugural-dissertation zur Erlangung der Doktorwürde der Naturwissenschaftlich-Mathematischen Gesamtfakultät der Ruprecht-Karls- Universität Heidelberg, Heidelberg.

Wallace, D. T.

1960 Early Paracas Textile Techniques, American Antiquity 26 (2), 279-281. https://doi.org/10.2307/276210

1962 Cerrillos, an Early Paracas Site in Ica, Peru, American Antiquity 27 (3), 303-314. https://doi. org/10.2307/277797

1963 Early Horizon Ceramics in the Cañete Valley of Peru, Nawpa Pacha 1, 35-38, Berkely.

Williams, C. y M. Pazos

1974 Inventario, catastro y delimitación del patrimonio arqueológico del valle de Ica, Instituto Nacional de Cultura, Centro de Investigación y Restauración de Bienes Monumentales, Lima.

Recepción: marzo de 2017

Aceptación: mayo de 2017 